This is the author's final, peer-reviewed manuscript as accepted for publication. The publisher-formatted version may be available through the publisher's web site or your institution's library.

\title{
Solar thermochemical production of ammonia from water, air and sunlight: thermodynamic and economic analyses
}

Ronald Michalsky, Bryon J. Parman, Vincent Amanor-Boadu, Peter H. Pfromm

\section{How to cite this manuscript}

If you make reference to this version of the manuscript, use the following information:

Michalsky, R., Parman, B. J., Amanor-Boadu, V., \& Pfromm, P. H. (2012). Solar thermochemical production of ammonia from water, air and sunlight: Thermodynamic and economic analyses. Retrieved from http://krex.ksu.edu

\section{Published Version Information}

Citation: Michalsky, R., Parman, B. J., Amanor-Boadu, V., \& Pfromm, P. H. (2012).

Solar thermochemical production of ammonia from water, air and sunlight:

Thermodynamic and economic analyses. Energy, 42(1), 251-260.

Copyright: () 2012 Elsevier Ltd.

Digital Object Identifier (DOI): doi:10.1016/j.energy.2012.03.062

Publisher's Link: http://www.sciencedirect.com/science/article/pii/S0360544212002654

This item was retrieved from the K-State Research Exchange (K-REx), the institutional repository of Kansas State University. K-REx is available at http://krex.ksu.edu 


\title{
Solar thermochemical production of ammonia from water, air and sunlight: thermodynamic and economic analyses
}

\author{
Ronald Michalsky ${ }^{1,2}$, Bryon J. Parman ${ }^{3,4}$, Vincent Amanor-Boadu ${ }^{4}$, Peter H. Pfromm ${ }^{2}$ \\ ${ }^{1}$ NSF IGERT associate in biorefining, ${ }^{2}$ Department of Chemical Engineering, \\ ${ }^{3}$ NSF IGERT trainee in biorefining, ${ }^{4}$ Department of Agricultural Economics, \\ Kansas State University, Manhattan, Kansas, 66506, U.S.A.
}

\begin{abstract}
Ammonia is an important input into agriculture and is used widely as base chemical for the chemical industry. It has recently been proposed as a sustainable transportation fuel and convenient one-way hydrogen carrier. Employing typical meteorological data for Palmdale, CA, solar energy is considered here as an inexpensive and renewable energy alternative in the synthesis of $\mathrm{NH}_{3}$ at ambient pressure and without natural gas. Thermodynamic process analysis shows that a molybdenum-based solar thermochemical $\mathrm{NH}_{3}$ production cycle, conducted at or below $1500 \mathrm{~K}$, combined with solar thermochemical $\mathrm{H}_{2}$ production from water may operate at a net-efficiency ranging from $23-30 \%$ (lower heating value of $\mathrm{NH}_{3}$ relative to the total energy input). Net present value optimization indicates ecologically and economically sustainable $\mathrm{NH}_{3}$ synthesis at above about 160 tons $\mathrm{NH}_{3}$ per day, dependent primarily on heliostat costs (varied between 90 and 164 dollars $/ \mathrm{m}^{2}$ ), $\mathrm{NH}_{3}$ yields (ranging from $13.9 \mathrm{~mol} \%$ to stoichiometric conversion of fixed and reduced nitrogen to $\mathrm{NH}_{3}$ ), and the $\mathrm{NH}_{3}$ sales price. Economically feasible production at an optimum plant capacity near 900 tons $\mathrm{NH}_{3}$ per day is shown at relative conservative technical assumptions and at a reasonable $\mathrm{NH}_{3}$ sales price of about $534 \pm 28$ dollars per ton $\mathrm{NH}_{3}$.
\end{abstract}

Corresponding Author: e-mail: pfromm@ksu.edu; phone: +1 785532 4312; fax: 785532-7372, postal address: 1036 Durland Hall, Kansas State University, Manhattan, KS 66506

Keywords: Hydrogen; Methane; Fertilizer; Solar; Electricity; Economics; Infrastructure. 


\section{Introduction}

The U.S. Census Bureau estimates that between 1900 and 2000, the world's population grew from 1.6 billion to 6.0 billion, and is projected to reach 9.0 billion by 2050 [1]. Global human population growth is projected to increase the strain on current natural resources, such as land, fossil hydrocarbons, and fresh water, if technological advances are not made in the production of products and services using these resources.

While technological advances in agriculture in the $20^{\text {th }}$ century - chemical fertilizers, mechanization, breeding, genetic improvement, chemical pest control, processing and storage systems - have contributed to vastly increase the productivity of land globally, the interface between energy and fertilizer production, especially ammonia, promises to challenge the agricultural productivity in the future. At present, over 100 million metric tons of $\mathrm{NH}_{3}$ [2] are produced annually, driven by increasing food demand and the need for higher crop yields [3]. $\mathrm{NH}_{3}$ is the single-most important synthetic fertilizer, accounting for $58 \mathrm{wt} \%$ of all fertilizer consumed for example in the USA in 2007 [4]. Its role in the production of bio-energy feedstock and its potential use in solar-derived $\mathrm{H}_{2}$ storage [5-7] or as a liquid fuel [8,9] augment its criticality and importance in the global economy.

$\mathrm{NH}_{3}$ easily reaches the U.S. Department of Energy 2015 hydrogen storage target for $\mathrm{H}_{2}$ based transportation fuels $[8,10]$ or it can be blended into diesel for direct combustion in modified diesel engines releasing mainly $\mathrm{H}_{2} \mathrm{O}$ and $\mathrm{N}_{2}$ as combustion-products [11]. If these competitive uses and the duty of the agricultural industry to feed a growing global population at reasonable prices are to be realized new and innovative $\mathrm{NH}_{3}$ synthesis technology will likely be required.

Industrially, the Haber-Bosch process synthesizes $\mathrm{NH}_{3}$ by shifting the reaction equilibrium of a $\mathrm{N}_{2} / \mathrm{H}_{2}$ gas mixture at high pressure (about $30 \mathrm{MPa}$ ) towards formation of ideally

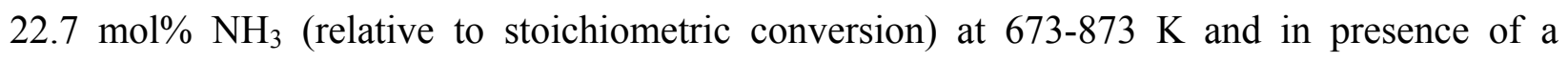
catalyst [12]. The energy-intensive process [13], including natural gas/steam reforming for $\mathrm{H}_{2}$ production (accounting for approximately 84\% of the total energy required), consumes 28-40 $\mathrm{GJ} / \mathrm{t} \mathrm{NH}_{3}$ in form of natural gas $[12,14]$ (about $1-2 \%$ of the world's annual energy production [15]). Approximately $2.3 \mathrm{t}$ of fossil-derived $\mathrm{CO}_{2}$ are generated per $\mathrm{t} \mathrm{NH}_{3}$ synthesized [14]. Employing steam-reforming of coal increases the energy required for $\mathrm{NH}_{3}$ production even further (about 47.6-165.9 GJ/t NH$)$ and increases the associated generation of fossil $\mathrm{CO}_{2}(16.7 \mathrm{t}$ 
$\left.\mathrm{CO}_{2} / \mathrm{t} \mathrm{NH}_{3}\right)[6,14]$. Economies of scale have dictated current Haber-Bosch facilities producing above about 1,500 $\mathrm{t} \mathrm{NH}_{3}$ per day, consuming significant quantities of natural gas and influencing that commodity's price trend. This in turn has a direct impact on $\mathrm{NH}_{3}$ prices and their volatility.

Various alternatives proposed for nitrogen fixation from the atmosphere via synthesis of $\mathrm{NH}_{3}$, including catalytic formation of $\mathrm{NH}_{3}$ near ambient temperature and pressure in the liquid phase [16] and electrochemical $\mathrm{NH}_{3}$ synthesis [17] have not yet reached maturity. Solar thermochemical $\mathrm{NH}_{3}$ synthesis at ambient pressure is a proposed remedy to some of the difficulties associated with the Haber-Bosch process [5, 18-21]. Reactive $\mathrm{NH}_{3}$ synthesis via a two-step solar thermochemical cycle of metal oxide nitridation and metal nitride hydrolysis [19, 22] has been demonstrated to form significant quantities of $\mathrm{NH}_{3}$ from air and water at near 0.1 MPa [19]. The process neither requires a catalyst nor a fossil hydrogen source. The energy required for the generation of $\mathrm{H}_{2}$ via $\mathrm{H}_{2} \mathrm{O}$ splitting and for the reductive cleavage of $\mathrm{N}_{2}$ is supplied in form of solar energy $[18,20]$. Concentrated solar radiation, absorbed at elevated temperature in an endothermic metal oxide reduction, creates a metal nitride in the presence of $\mathrm{N}_{2}$. The fixed nitrogen is, thereafter, released from the solid metal nitride as $\mathrm{NH}_{3}$ in an exothermic steam hydrolysis reaction. Given the abundance of solar radiation in many areas of the world, this approach has the potential to produce $\mathrm{NH}_{3}$ sustainably and facilitates simultaneously storage of intermittently available solar energy [23, 24].

Solid carbon (biomass or charcoal) has been suggested as reducing agent of the metal oxide in the process discussed above $[18,20]$. However, carbon may not be available in the right quantities and proximity to the manufacturing plant, requiring transportation or production, using up arable land and requiring expensive and energy-intensive processing $[25,26]$. On the other hand, reactants forming metal oxides which can be reduced with $\mathrm{H}_{2}$ unfortunately tend to not fix $0.1 \mathrm{MPa} \mathrm{N}_{2}$ in form of metal nitrides and show low $\mathrm{NH}_{3}$ yields when reacting their nitrides with steam [21]. Molybdenum considered here represents a trade-off [21]: The oxide, $\mathrm{MoO}_{2}$, that is formed during nitride $\left(\mathrm{Mo}_{2} \mathrm{~N}\right)$ hydrolysis at above $800 \mathrm{~K}$ can be reduced [27] and nitridated with moderate yields in $\mathrm{H}_{2} / \mathrm{N}_{2}$ gas mixtures in the range of 800 to $1500 \mathrm{~K}[28,29]$. Given the relative high ionicity of the nitride [30,31], significant quantities of $\mathrm{NH}_{3}$ are liberated during the hydrolysis of $\mathrm{Mo}_{2} \mathrm{~N}$ at atmospheric pressure.

The work presented here conceptually assesses the technical and economic attractiveness of Mo-based solar thermochemical $\mathrm{NH}_{3}$ synthesis in the absence of any carbonaceous material or 
natural gas as feedstock or for energy (Fig.1). Experimentation towards the technical feasibility of the reaction cycle is described elsewhere [20].

A thermodynamic analysis for synthesizing $\mathrm{NH}_{3}$ in a two-step solar thermochemical reaction cycle from $\mathrm{H}_{2}$ and $\mathrm{N}_{2}$ with a Mo-based reactant at $0.1 \mathrm{MPa}$ (Fig.1) is presented in section 2.1. Section 2.2 determines plant capacity and energy efficiency and $\mathrm{CO}_{2}$ emissions of the Haber-Bosch process implemented with natural gas as a benchmark for a process analysis of the proposed reaction cycle (Fig.2) in section 2.3. The analysis simulates an implementation of the reaction cycle with $\mathrm{H}_{2}$ generated via a well-studied solar thermochemical $\mathrm{H}_{2} \mathrm{O}$ splitting cycle using zinc $[24,32,33]$. In practice, the proposed $\mathrm{NH}_{3}$ synthesis may be implemented with other solar-to-hydrogen technologies [33]. Section 3.1 estimates investment costs for unit operations and chemical commodities used in section 3.2 that develops an economical optimization model for scalable solar thermochemical $\mathrm{NH}_{3}$ synthesis. The model is evaluated and discussed employing net present value calculations in section 3.3. Section 3.4 shows that the proposed concept is economically attractive under fairly conservative assumptions.

\section{Thermochemical $\mathrm{NH}_{3}$ synthesis cycle}

The Gibbs free energy of formation for a metal nitride is relatively small compared to the corresponding oxide. Thus, only a few metals such as Mo allow simultaneously for oxide reduction with $\mathrm{H}_{2}$ and reductive cleavage of dinitrogen at $0.1 \mathrm{MPa}[21,28,29]$. Mo is shown here to be a promising reactant for solar thermochemical $\mathrm{NH}_{3}$ synthesis.

To estimate the equilibrium reaction yield achievable in a system closed to mass transfer, the free energy of reaction, $\Delta_{r x n} g$, was computed based on the literature [27]. The absolute error of energy of formation data was estimated previously with $\pm 3 \mathrm{~kJ}$ [34] and was taken as $2 \%$ of the value in $\mathrm{kJ} / \mathrm{mol}$. The computed formation of $\mathrm{Mo}_{2} \mathrm{~N}$ was extrapolated at $>800 \mathrm{~K}$ using a linear fit $\left(\mathrm{R}^{2}>0.999\right)$. With the free energy computations in hand, the equilibrium constants, $K_{\text {eq }}$, were determined at atmospheric pressure taking the total number of chemical species in the system for simplicity as the arithmetic mean of the number of reactants and the number of products at complete conversion [35]. This allows solving the elemental mol balances of the given reaction system symbolically ("live" Symbolics, Mathcad 13) as a function of $K_{e q}$, that is yielding the equilibrium composition of the reaction system as a function of temperature, $T$, at $0.1 \mathrm{MPa}$. 


\subsection{Thermodynamic analysis}

Conversion of solar energy is accomplished by thermochemical reduction of Mo(IV) oxide with $\mathrm{H}_{2}$ to Mo metal (Eq.1):

$$
\begin{aligned}
& 2 \mathrm{MoO}_{2(s)}+4 \mathrm{H}_{2} \leftrightarrow 2 \mathrm{Mo}_{(s)}+4 \mathrm{H}_{2} \mathrm{O} \\
& \Delta_{r x h} h_{1500 \mathrm{~K}} \approx 130 \pm 25 \mathrm{~kJ} / \mathrm{mol} \mathrm{N}
\end{aligned}
$$

$\Delta_{r x n} g$ of Eq. 1 indicates that the reaction equilibrium is favored thermodynamically at above ca. $1428 \mathrm{~K}$ (Fig.3A). The chemical energy stored in the endothermic metal formation (the enthalpy of reaction, $\Delta_{r x n} h$ [27]) allows subsequently for slightly exothermic $\mathrm{N}_{2}$ fixation in form of metal nitridation (Eq.2) favorably at lower temperatures (Fig.3B):

$$
\begin{aligned}
& 2 M o_{(s)}+1 / 2 N_{2} \leftrightarrow \mathrm{Mo}_{2} N_{(s)} \\
& \Delta_{r x n} h_{800 K} \approx-63.2 \pm 0.8 \mathrm{~kJ} / \mathrm{mol} \mathrm{N}
\end{aligned}
$$

The yield $(Y=$ mol solid reaction product formed $/$ mol solid product at stoichiometric conversion) for reaction 1 or 2 is below stoichiometric conversion at thermodynamic equilibrium (Eq.1 at ca. $1428 \mathrm{~K}$, Eq. 2 at ca. $1115 \mathrm{~K}$, assuming $0.1 \mathrm{MPa}$ ) (Fig.3). However, given the nonequilibrium situation (mass exchange) in an actual flow-through reactor, and assuming a high effective reactant surface, stoichiometric conversion for both reactions is assumed below. The over-stoichiometric supply of $\mathrm{H}_{2}$ (section 2.3), may account for excess $\mathrm{MoO}_{2}$ formed during nitride hydrolysis from Mo that may not have converted to $\mathrm{Mo}_{2} \mathrm{~N}$ during the nitridation.

The fraction of reactive nitrogen ions yielded in the solid state due to the electron transfer between bonding Mo 4d, Mo 5s and N 2p orbitals allows for exothermic formation of $\mathrm{NH}_{3}$ when the nitrogen in the solid phase is substituted with more electronegative oxygen (Eq.3):

$$
\begin{aligned}
& \mathrm{Mo}_{2} \mathrm{~N}_{(s)}+4 \mathrm{H}_{2} \mathrm{O} \leftrightarrow 2 \mathrm{MoO}_{2(s)}+\mathrm{NH}_{3}+5 / 2 \mathrm{H}_{2} \\
& \Delta_{r x n} h_{800 \mathrm{~K}} \approx-168 \pm 29 \mathrm{~kJ} / \mathrm{molN}
\end{aligned}
$$

Uncharged $\mathrm{N}^{0}$ in the interstitial space of the metal or metal nitride crystal may form $\mathrm{N}_{2}$ upon nitride corrosion (Eq.4):

$$
\begin{aligned}
& \mathrm{Mo}_{2} \mathrm{~N}_{(\mathrm{s})}+4 \mathrm{H}_{2} \mathrm{O} \leftrightarrow 2 \mathrm{MoO}_{2(\mathrm{~s})}+1 / 2 \mathrm{~N}_{2}+4 \mathrm{H}_{2} \\
& \Delta_{r x n} h_{800 \mathrm{~K}} \approx-114 \pm 29 \mathrm{~kJ} / \mathrm{mol} \mathrm{N}
\end{aligned}
$$

The assumptions below (see 2.3) are based on experimental results (manuscript in preparation) for hydrolysis of $25.5 \pm 0.5 \mathrm{wt} \% \mathrm{Mo}_{2} \mathrm{~N}$ powder (balance Mo, $17 \pm 8 \mu \mathrm{m}$ average particle diameter, $429 \pm 3 \mathrm{~m}^{2} / \mathrm{kg}$ BET surface area) at $773 \mathrm{~K}$ with steam supplied for $1 \mathrm{~h}$ at a rate of 0.91 
$\pm 0.02 \mathrm{ml}_{(\mathrm{STP})} / \mathrm{min}$. The simulation assumes either $Y_{3}=100 \mathrm{~mol} \%, Y_{4}=0$ (stoichiometric conversion), or $Y_{3}=13.9 \mathrm{~mol} \%, Y_{4}=9.1 \mathrm{~mol} \%$. Decreasing the hydrolysis temperature (Fig.4) or increasing the availability of effective reactive surface sites may allow increasing the yield of $\mathrm{NH}_{3}$ in practice. Endothermic decomposition of $\mathrm{Mo}_{2} \mathrm{~N}$ (Eq.2, when favoring the species on the left side) was neglected at this point due to a positive $\Delta_{r x n} g$ at $800 \mathrm{~K}$. Oxidation of $\mathrm{MoO}_{2}$ to $\mathrm{MoO}_{3}$ [28] is not favored at equilibrium $\left(105.2 \mathrm{~kJ} / \mathrm{mol}\right.$ oxide $\Delta_{r x n} g$ at $800 \mathrm{~K}$ [27]) but driven when the equilibrium is not established due to $\mathrm{MoO}_{3}$ vapor formation $\left(\mathrm{MoO}_{3}\right.$ boils at about 1428 $\mathrm{K})$. This can be reduced or avoided by low hydrolysis temperatures, low steam flow rates and short reaction times.

The overall reaction represents an alternative for realizing the Haber-Bosch reaction $\left(1 / 2 \mathrm{~N}_{2}+3 / 2 \mathrm{H}_{2} \leftrightarrow \mathrm{NH}_{3}\right)$ near $0.1 \mathrm{MPa}$. The enthalpy required for breaking the $\mathrm{N}_{2}$ triple bond is supplied indirectly in form of concentrated solar radiation providing the heat (at $1500 \mathrm{~K}$ ) for the endothermic reduction of Mo(IV) oxide to Mo metal (Eq.1). The metal is utilized to cleave and electrochemically reduce dinitrogen (Eq.2) increasing the metallic oxidation state formally to $\mathrm{Mo}^{+3 / 2}$ in $\mathrm{Mo}_{2} \mathrm{~N}[30,31] . \mathrm{Mo}_{2} \mathrm{~N}$ is further oxidized to $\mathrm{Mo}(\mathrm{IV})$ when reacted with $\mathrm{H}_{2} \mathrm{O}$ to liberate $\mathrm{NH}_{3}$ (Eq.3). The heat released from Eq. 2-4 is partly integrated [36] (see 2.3). The significant amount of energy required to form $\mathrm{H}_{2}$ from $\mathrm{H}_{2} \mathrm{O}$ (Fig.2) is supplied as solar radiation at $2000 \mathrm{~K}$ employing a two-step solar thermochemical cycle of endothermic $\mathrm{ZnO}$ dissociation (about 679.2 $\mathrm{kJ}$ per $3 / 2 \mathrm{~mol} \mathrm{H} \Delta_{r x n} h$ at $2000 \mathrm{~K}$ ), quenching of the $\mathrm{Zn} / \mathrm{O}_{2}$ vapor leaving the reactor, and exothermic oxidation of the condensed $\mathrm{Zn}$ with $\mathrm{H}_{2} \mathrm{O}$ at $400 \mathrm{~K}$ (about $-156.6 \mathrm{~kJ}$ per $3 / 2 \mathrm{~mol} \mathrm{H}_{2}$ $\Delta_{r x n} h$ at $400 \mathrm{~K}$ ) recycling $\mathrm{ZnO}$ and producing $\mathrm{H}_{2}$ (both computed at $0.1 \mathrm{MPa}$ and assumed with stoichiometric conversion). This well-studied cycle has been discussed elsewhere [24, 32].

\subsection{The scale of industrial $\mathrm{NH}_{3}$ synthesis}

As a benchmark, the Aspen Plus (V7.0) Ammonia Model [37] was used to simulate the industrial $\mathrm{NH}_{3}$ production using natural gas as a feedstock. The model comprises a reforming unit converting a desulfurized hydrocarbon feed with steam (primary reformer, 3.1-3.3 $\mathrm{MPa}$, 775-1064 K) and air (secondary reformer, 2.9-3.1 MPa, 1251-1530 K) into $\mathrm{H}_{2}$ and carbon oxides. Subsequently, $\mathrm{CO}$ is converted catalytically $(2.7-2.9 \mathrm{MPa}, 483-721 \mathrm{~K})$ to $\mathrm{CO}_{2}$ that is removed with $\mathrm{NH}_{3}$ forming an ammonium hydrogen carbonate byproduct. The synthesis gas obtained is freed from traces of $\mathrm{CO}$ and $\mathrm{CO}_{2}$ employing a nickel catalyst to form $\mathrm{CH}_{4}$ 
(methanizer). Thereafter, $\mathrm{NH}_{3}$ is synthesized at $28.4-29.2 \mathrm{MPa}$ and $686-799 \mathrm{~K}$ over a promoted iron catalyst. The major fraction of the $23.9 \mathrm{~mol}_{\mathrm{o} \mathrm{NH}}$ in the synthesis loop (about $33.9 \mathrm{~mol} \%$ nitrogen-to- $\mathrm{NH}_{3}$ conversion) is liquefied via refrigeration $(27.5 \mathrm{MPa}, 288-304 \mathrm{~K})$ and stored at 3 MPa. The model estimates the thermodynamic properties of gases at high temperature and pressure using a modified Redlich-Kwong equation of state (RKS-BM). Liquid and vapor properties in the $\mathrm{CO}_{2}$ scrubbing unit are modeled with an electrolyte NRTL or a Redlich-Kwong equation of state model respectively. A detailed description of the Haber-Bosch modeling is provided elsewhere [37].

Overall, the process converts approximately $35.9 \mathrm{t} / \mathrm{h}$ natural gas $\left(80.0 \mathrm{~mol} \% \mathrm{CH}_{4}, 17.7\right.$ mol\% $\mathrm{C}_{2} \mathrm{H}_{6}$, balance hydrocarbons and air, at $3.8 \mathrm{MPa}$ and $303 \mathrm{~K}$ ) with $308.5 \mathrm{t} / \mathrm{h}$ air at $302 \mathrm{~K}$ and $69.0 \mathrm{t} / \mathrm{h}$ water at $293 \mathrm{~K}$ (both at $0.1 \mathrm{MPa}$ ) to $27.5 \mathrm{t} / \mathrm{h}$ liquid anhydrous ammonia $(99.6 \mathrm{~mol} \%$ $\left.\mathrm{NH}_{3}, 2 \mathrm{MPa}, 306 \mathrm{~K}\right), 126.9 \mathrm{t} / \mathrm{h}$ ammonium bicarbonate salt $\left(98.7 \mathrm{~mol} \% \mathrm{NH}_{4} \mathrm{HCO}_{3}, 0.1 \mathrm{MPa}, 293\right.$ $\mathrm{K}$ ), and $259.0 \mathrm{t} / \mathrm{h}$ flue gas $\left(7.0 \mathrm{~mol} \% \mathrm{CO}_{2}, 16.1 \mathrm{~mol} \% \mathrm{H}_{2} \mathrm{O}\right.$, balance $\mathrm{N}_{2}, \mathrm{O}_{2}$, and $\mathrm{Ar}, 0.1 \mathrm{MPa}$, $333 \mathrm{~K})$. To compare this to the discontinuous operation of the solar thermochemical $\mathrm{NH}_{3}$ synthesis in section 2.3, this equates production of about 1,324 $\mathrm{t} \mathrm{NH}_{3}$ per day (as anhydrous ammonia or ammonium salt, assuming $24 \mathrm{~h} / \mathrm{d}$ operation).

The enthalpy balance of the process indicates a net heat duty of about $289 \mathrm{MW}$, mainly due to the heat required in the reforming unit and the $\mathrm{CO}_{2}$ stripper and the electricity consumed for synthesis gas compression. Taking the lower heating value (LHV) of natural gas at $31.89 \mathrm{GJ} / \mathrm{t}$ [38] results in further consumption of about $32.6 \mathrm{t} / \mathrm{h}$ natural gas and $549.7 \mathrm{t} / \mathrm{h}$ air generating $582.3 \mathrm{t} / \mathrm{h}$ flue gas $\left(9.9 \mathrm{~mol} \% \mathrm{CO}_{2}, 18.3 \mathrm{~mol} \% \mathrm{H}_{2} \mathrm{O}\right.$, balance $\mathrm{N}_{2}$ and $\left.\mathrm{Ar}\right)$. This yields total $\mathrm{CO}_{2}$ emissions of the process - flue gas - at about $2.17 \mathrm{t} \mathrm{CO}_{2}$ per $\mathrm{t} \mathrm{NH}_{3}$. The energy efficiency can be estimated with $46.9 \%$ (the LHV of $1,324 \mathrm{t} / \mathrm{d} \mathrm{NH}_{3}$ relative to the LHV of $1,644 \mathrm{t} / \mathrm{d}$ natural gas).

\subsection{Numerical process analysis}

Given its conceptual state a conceivable solar thermochemical process that is converting air, desalinated water, and sunlight into liquid ammonia and compressed oxygen (Fig.5) was analyzed similar to other thermochemical processes reported in the literature [23, 36, 39]. To estimate the plant layout mass and energy balances were solved iteratively (Generalized Reduced Gradient nonlinear optimization code, $10^{2}$ iteration steps, $10^{-4}$ minimum sensitivity, Excel 2003) at steady-state and as a function of a variable $\mathrm{NH}_{3}$ capacity. Two scenarios were computed: First, 
assuming $Y_{3}=100 \mathrm{~mol} \%, Y_{4}=0$ (see 2.1), and the ratio of gaseous reactant required at minimum to the amount of gaseous reactant supplied to any reaction, $r_{\text {gas }}$, of $90 \mathrm{~mol} \%$, "ideal operation". The second, rather "conservative operation", assumes $Y_{3}=13.9 \mathrm{~mol} \%, Y_{4}=9.1 \mathrm{~mol} \%$, and $r_{\text {gas }}=$ $67 \mathrm{~mol} \%$.

To analyze the performance of the envisioned plant located in a suitable geographic region typical meteorological data from the updated National Solar Radiation Data Base (NSRDB) was used [40, 41]. The hourly direct normal irradiance values provided by the database were averaged over a typical meteorological year to identify several regions in the southwestern U.S. with an averaged normal irradiance in the range of $7.01-7.81 \mathrm{kWh} / \mathrm{m}^{2} / \mathrm{d}$. The analysis presented here assumes a yearly-averaged direct normal irradiance of $7.48 \mathrm{kWh} / \mathrm{m}^{2} / \mathrm{d}$ (that is 1 $\mathrm{kW} / \mathrm{m}^{2}$ for annualized $7.48 \mathrm{~h} / \mathrm{d}$ ), based on data for 1997-2005, Palmdale Airport, CA, USA (approximately $80 \mathrm{~km}$ linear distance to the Pacific).

Solar radiation is concentrated via heliostats and absorbed at 1500 or $2000 \mathrm{~K}$ respectively (Fig.5) with an efficiency of solar radiation converted to chemically stored energy (dimensionless mean flux concentration ratio at $10^{4}$, for a detailed description see [24]) assumed at 0.78 (Fig.6). The radiation is received by a series of reactors at $100 \mathrm{~m}$ above ground (similar in appearance to the Solar Two power tower, Mojave Desert, CA, USA; or the PS10 and PS20 plants near Seville, Spain) splitting $\mathrm{H}_{2} \mathrm{O}$ into $\mathrm{H}_{2}$ and $\mathrm{O}_{2}\left(2.5 \times 2.5 \times 5.0 \mathrm{~m}\right.$ reactor volume, $V_{R}$, Mo-alloy), or converting $\mathrm{H}_{2}$ and $\mathrm{N}_{2}$ to $\mathrm{NH}_{3}\left(15 \times 15 \times 25 \mathrm{~m} V_{R}\right.$, ceramic lining). $V_{R}$ was estimated assuming $1 \mathrm{~min}$ residence time of the gaseous species at a given temperature in the reactor (using a molar ratio of $\mathrm{N}_{2}$ sweep gas to $\mathrm{ZnO}$ of 0.1 [32]). In practice $V_{R}$ will be determined empirically by reaction kinetics for a reactant with optimized composition and by the heliostat area required per reactor for providing heat at a desired temperature.

Sensible, $\Delta_{\text {sen }} h$, and latent, $\Delta_{\text {lat }} h$, heat and the $\Delta_{r x n} h$ of exothermic reactions [27] are recovered and integrated at a ratio of 0.6 (that is heat losses at about 40\%) [36] estimating heat exchange areas of $1.44 \times 10^{4} \mathrm{~m}^{2}$ for temperatures up to $2000 \mathrm{~K}$ (lined with molybdenum disilicide) or $8.47 \times 10^{4} \mathrm{~m}^{2}<1500 \mathrm{~K}$ (Fig.6). This is assuming replication of the production described in section 2.2. The remaining heat is removed via dry (air) cooling $\left(5.71 \times 10^{5} \mathrm{~m}^{2}\right.$ heat exchange area, $40 \mathrm{~K}$ effective $\Delta T_{\text {air }}, 2 \mathrm{kPa}$ pressure losses [42], efficiency of fans and compressors assumed with 0.86 [43]). Although shown to be by a factor of 4-6 more energy- 
intensive and by a factor of 4-12 more capital-intensive than wet cooling, dry cooling was employed due to the crucial role of water availability [44].

The $\mathrm{N}_{2}$ is required only at industrial-grade purity (as sweep gas and feedstock) and is produced via membrane permeation (based on literature values for gas permeability and diffusivity for polysulfone fibers [45]) yielding at $0.2 \mathrm{MPa}$ trans-membrane pressure an effective membrane area of ca. $8.48 \times 10^{5} \mathrm{~m}^{2}$. By-product $\mathrm{O}_{2}$ (Table 1) is compressed isentropically and stored. $\mathrm{NH}_{3}$ is separated from its synthesis vapor and liquefied via cooling and compression to $306 \mathrm{~K}$ and $2 \mathrm{MPa}$ (see 2.2) and stored in steel tanks. $\mathrm{H}_{2}$ and $\mathrm{N}_{2}$ gas mixtures recovered from the $\mathrm{NH}_{3}$ synthesis cycle are enriched with $\mathrm{H}_{2}$ generated in the $\mathrm{H}_{2}$ synthesis cycle and desiccated with a silica gel bed $\left(0.4 \mathrm{~g} \mathrm{H}_{2} \mathrm{O} / \mathrm{g} \mathrm{SiO}_{2}\right.$ adsorption capacity [46], $200 \mathrm{~K}$ maximum $\Delta T_{\text {gas }}$ between $\mathrm{H}_{2} \mathrm{O}$ ad- and desorption, $10 \mathrm{kPa}$ pressure drop assumed for all solid beds). Traces of $\mathrm{Ar}, \mathrm{CO}_{2}$, and $\mathrm{Zn}$ or $\mathrm{MoO}_{3}$ vapor have been neglected for simplicity.

Given the net energy content of $\mathrm{NH}_{3}$ and neglecting the energy stored in the separation of $\mathrm{O}_{2}$ from air, conversion of solar energy to $\mathrm{NH}_{3}$ was estimated with an efficiency of about 23$30 \%$ at maximum ( $\mathrm{LHV}$ of $\mathrm{NH}_{3}$ relative to the total energy requirement, including net electricity as solar heat-equivalent, for conservative or ideal operation, respectively) (Table 1). This energy is released in form of heat when $\mathrm{NH}_{3}$ is combusted (e.g., as transportation fuel) [11] or in form of $\mathrm{H}_{2}$ when $\mathrm{NH}_{3}$ is used as a single-use hydrogen carrier $[6,7,9]$. The maximum efficiency as estimated is below $46.9 \%$ estimated for the $\mathrm{NH}_{3}$ synthesis with natural gas at this scale (section 2.2) but within the range estimated for the industrial $\mathrm{NH}_{3}$ synthesis via steam reforming with natural gas or coal respectively, i.e., 11-66\% (Table 1).

The total electricity required for the proposed process (assuming as a worst-case scenario all grid-electricity is generated from coal-fired power plants emitting 0.91 t $\mathrm{CO}_{2} / \mathrm{MWh}$ [47]) results in $\mathrm{CO}_{2}$ emissions in the range of $0.62-1.08 \mathrm{t} \mathrm{CO}_{2} / \mathrm{t} \mathrm{NH}_{3}$. That is a net reduction of fossil $\mathrm{CO}_{2}$ emissions by $50-71 \%$ relative to the current $\mathrm{NH}_{3}$ synthesis with natural gas (see 2.2) or up to $96 \%$ when avoiding the use of coal feedstock in favor of biomass (see 1.).

\section{Economic feasibility}

The production of $\mathrm{NH}_{3}$ presented in section 2 comprises two phases: (i) $\mathrm{H}_{2}$ generation via a two-step solar thermochemical $\mathrm{H}_{2} \mathrm{O}$ splitting cycle, and (ii) solar thermochemical $\mathrm{NH}_{3}$ synthesis from desalinated water, air and $\mathrm{H}_{2}$. It is envisioned that the required solar energy is 
harvested with an array of heliostats concentrating solar radiation that is received by a reactor placed atop a central collector tower, i.e., " $\mathrm{H}_{2}$ towers" if generating $\mathrm{H}_{2}$, or " $\mathrm{NH}_{3}$ towers" if generating $\mathrm{NH}_{3}$ (Fig.2 and 5).

If the production described in section 2.2 is to be replicated by this process at "ideal operation", it will require $33.2 \mathrm{t} \mathrm{Mo,} 17.0 \mathrm{t} \mathrm{Zn}, 0.48 \mathrm{~km}^{2}$ lens area for concentration of sunlight, $A_{\text {lens }}$, utilized by the $\mathrm{NH}_{3}$ synthesis cycle, and $2.95 \mathrm{~km}^{2} A_{\text {lens }}$ utilized by the $\mathrm{H}_{2}$ synthesis cycle (Fig.5). On the other hand, "conservative operation" would lead to $239.1 \mathrm{t}$ Mo, $17.0 \mathrm{t} \mathrm{Zn,} 1.11$ $\mathrm{km}^{2} A_{\text {lens }}$ to synthesize $\mathrm{NH}_{3}$, and $3.10 \mathrm{~km}^{2} A_{\text {lens }}$ to produce $\mathrm{H}_{2}$. The increased amount of Mo does not significantly affect capital costs (see 3.1). However, the increased land requirements (increased totally by $22.7 \%$ for provision of sensible and latent heat and $\Delta_{r x n} h$ of Eq.1) under the "conservative operation" lead to a significantly increased amount of capital that needs to be raised for reactors and solar concentrators. A process summary is given in Table 1 and Figure 6.

\subsection{Data sources}

The mass and energy balances were utilized to generate a generic list of components and equipment required for realizing the proposed process (see 2.3). Data estimates as realistic as possible were obtained from equipment manufacturers, service providers and operating facilities. A summary for fixed costs dependent on or independent of the $\mathrm{NH}_{3}$ capacity or operational costs is given in Table 2, 3 or 4 respectively.

The operating costs including heliostat maintenance and service are assumed at $3 \%$ of total heliostat costs. Labor is assumed based upon plant size and skill level. Air compressors and water pump costs are based upon gas/liquid mass flow and stream conditions. Variable costs are assumed to grow at an annual inflation rate of 3\%. Corporate income tax is set and maintained at its current level of $35 \% . \mathrm{NH}_{3}$ price is forecast using $10^{3}$ Monte Carlo simulations based on a 20year historical mean and standard deviation of U.S. prices (Fig.7). The projected $\mathrm{NH}_{3}$ price series drawn from the Monte Carlo model has a mean, median, or standard deviation of 522, 531 or 27 dollars/t $\mathrm{NH}_{3}$ respectively. It is assumed that variable costs per unit will be linear in production, with scale effects influencing the linearity of per unit cost over different production levels. 


\subsection{Economics of Solar Thermochemical $\mathrm{NH}_{3}$ Production}

The economics do not assume any kind of regulatory or public support for the technology proposed here. No credit is taken or subsidies are assumed for reduction of $\mathrm{CO}_{2}$ emissions, use of renewable vs. non-renewable resources in making the product, etc.

The $\mathrm{NH}_{3}$ plant is assumed to be a profit-maximizing/cost minimization business. Thus, it will select its fixed and variable costs to produce at an output level that maximizes the return to its investment. This assumption implies that a principal constraint in building such a plant is available capital, treating costs of capital as part of operating costs. Economic theory suggests that the plant would be built if it is economically feasible. Economic feasibility is defined here to mean the ability of the plant to return a positive net present value at a specified discount rate over a reasonable lifespan of the project. "Reasonable lifespan" is defined to imply a period prior to the need for major capital retrofitting of the plant, assumed in this case to be 20 years.

An optimization approach is adopted to evaluate the economic feasibility of building a solar thermochemical $\mathrm{NH}_{3}$ production plant using the foregoing technology. This approach is particularly helpful because of the physical plant constraints in the production process and the direct effects of these constraints on the plant's profitability. It is assumed that the output of $\mathrm{NH}_{3}$ in each scenario, $Z_{l m}$, is defined as:

$$
Z_{l m}=\delta_{l m} X_{N}, \quad l=1,2 ; m=1,2
$$

where $\delta_{l m}$ is a yield constant in $\mathrm{t} / \mathrm{h}$ per tower based on the technical efficiency of the towers, and $X_{N}$ is the quantity of $\mathrm{NH}_{3}$ towers (see 3.). The objective function of the optimization model is to maximize operational profits, $\pi$, by selecting the optimum number of $X_{N}$ given the expected market price, $p$, of $\mathrm{NH}_{3}$ and in cognizance of plant operational costs. The model is evaluated under two operational, $l$, and cost, $m$, conditions, yielding four scenarios:

- $\quad$ Scenario 1: ideal operation, conservative costs $(l, m=1)$

- Scenario 2: ideal operation, optimistic costs $(l=1, m=2)$

- Scenario 3: conservative operation, conservative costs $(l=2, m=1)$

- $\quad$ Scenario 4: conservative operation, optimistic costs $(l, m=2)$

Since the only choice variable is $X_{N}$, the optimization model may be presented as: 


$$
\begin{aligned}
\max \pi_{l m} & =p Z_{l m}\left(X_{N}\right)-C\left(Z_{l m}\right)-F_{Z_{l m}} \\
\text { s.t. } \rho_{l} X_{N} & \leq X_{H} \\
K_{l m, j_{l m}}-F_{Z_{l m}} & \geq b_{N_{l m}} X_{N}+b_{H_{l m}} X_{H} \\
X_{N}, X_{H} & \in[0, \infty) \\
X_{N}, X_{H} & \equiv I
\end{aligned}
$$

where $C\left(Z_{l m}\right)$ is the variable costs for producing $Z$ output and $F_{Z}$ is the fixed costs under each scenario. The number of $\mathrm{H}_{2}$ towers is a fixed proportion, $\rho$, of the number of $\mathrm{NH}_{3}$ towers. This constraint is set as an inequality because it is technically feasible to produce more $\mathrm{H}_{2}$ than required. The second constraint in Eq. 6 stipulates that available capital, $K_{l m}$, less the associated fixed costs, $F_{Z}$, must be higher than the acquisition costs of the two types of central tower systems. Available capital is evaluated $j$ times with particular characteristics to assess the effect of capital on the optimum output and profits. Since the optimization model is essentially choosing output using the number of $\mathrm{NH}_{3}$ and $\mathrm{H}_{2}$ towers, it is plausible to present all plant fixed costs, i.e., the coefficients $b_{N l m}$ and $b_{H l m}$, in terms of towers. The final two constraints indicate that the number of towers is always a positive non-zero integer to ensure that production does occur. Table 5 provides a summary of the assumptions underlying the computed scenarios.

With regard to assumed costs, cost and quantity estimates for Scenario 1 - the baseline scenario - are provided in Table 2. Note that the product and sum of each tower specific column and the cost column gives the value of $b_{N 11}$ and $b_{H 11}$. In Scenario 2 the heliostat price is decreased from 164 to 90 dollars $/ \mathrm{m}^{2}$ [33] and the price of heat exchangers for temperatures up to $2000 \mathrm{~K}$ is reduced by two thirds from 467 to 155 dollars $/ \mathrm{m}^{2}$. This results in an overall cost per tower of 13.9 million dollars per $\mathrm{NH}_{3}$ tower or 53.3 million dollars per $\mathrm{H}_{2}$ tower. That is cost reductions relative to Scenario 1 of 3.76 or 28.1 million dollars per $\mathrm{NH}_{3}$ or $\mathrm{H}_{2}$ tower respectively. It should be noted that the cost of the $\mathrm{NH}_{3}$ tower accounts for major components of the overall process (Table 2 and 4). This shows that the impact of the heliostat investment costs for the $\mathrm{H}_{2}$ production cycle is quite significant. Correlating linearly with the area estimate for harvesting solar radiation (see 2.3 and Fig.6), about 74-86\% (conservative to ideal operation) of the total heliostat investment costs is absorbed in the construction of the $\mathrm{H}_{2}$ production cycle.

With regard to assumed process operation, Scenario 3 uses the cost estimates as shown in Table 2. However, the decrease in $Y_{3}$ and the increase in $Y_{4}$, results in an increased amount of heat and $\mathrm{H}_{2}$ required for recovering an increased amount of Mo from its oxide. This together 
with the decrease in $r_{\text {gas }}$ results in an increased amount of gas that has to be processed increasing the number of required $\mathrm{NH}_{3}$ or $\mathrm{H}_{2}$ towers respectively. This, altogether, reduces the overall costs per $\mathrm{NH}_{3}$ tower from 17.6 (Scenario 1) to 16.0 million dollars (Scenario 3) and increases the overall costs per $\mathrm{H}_{2}$ tower from 81.3 to 92.9 million dollars. Scenario 4 uses the same quantities per tower as that of Scenario 3 with the cost estimates of Scenario 2 resulting in investment costs of 13.4 million dollars per $\mathrm{NH}_{3}$ tower and 59.4 million dollars per $\mathrm{H}_{2}$ tower.

\subsection{Model Evaluation and Profitability}

The economic feasibility of the plant is determined by its ability to generate a positive net present value (NPV). Given that the only choice variable in the optimization model is $\mathrm{NH}_{3}$ output, the feasibility analysis presented here is conducted under optimal conditions by multiplying the prevailing price of $\mathrm{NH}_{3}$ (see 3.1, Fig.7) by the optimum quantity to get total revenue and adjusting that by operating costs in each period.

The plant is assumed to operate 365 days per annum (in agreement with the annualized solar insulation data employed, see 2.3), running a single labor shift. Assuming an inflation rate of $3 \%$, the cash flows from operations under the four scenarios are estimated. The NPV is then calculated for each scenario using a $10 \%$ discount rate. Total operating costs for the year includes labor, service contracts and utilities costs, presented on a per tower basis, as per discussion in section 3.2. The initial price of the $\mathrm{O}_{2}$ byproduct is assumed at its current market price of about 21 dollars/t, and allowed to grow naively at the assumed inflation rate of $3 \%$ per annum over the simulated 20 year period. Thus, the total plant revenue is enhanced by the revenues emanating from the sale of $\mathrm{O}_{2}$ in each period. Net revenues are adjusted for corporate taxes to provide the annual cash flow in each period. The economic feasibility based on NPV is presented as:

(7) $\quad N P V_{l m}=-F_{Z_{l m}}+\sum_{T=1}^{20}\left(\pi_{l m T}(1+D)^{-T}\right)$

where $D$ is the discount rate and $T$ is the relevant year.

Figure 8 displays the NPV and initial plant costs from Scenario 1 or 4 respectively. There exists a pattern of oscillating profitability in both scenarios shown. Scenario 1 shows a negative NPV at the initial output iteration increasing overall as output increases to an NPV of approximately 116.9 million dollars. The $4^{\text {th }}$ iteration's NPV is lower than the $3^{\text {rd }}$ iteration's 
since, at this point, an increase in output requires an additional $\mathrm{H}_{2}$ tower and thus allows for only a slight increase in overall output from the $3^{\text {rd }}$ to the $4^{\text {th }}$ iteration with a 116.7 million dollar increase in overall plant costs. This result also appears, albeit at different iterations, for Scenario 4 stemming from the same additional $\mathrm{H}_{2}$ tower construction requirements. However, Scenario 4 approaches, yet does not reach, a positive NPV within the domain of the model. Since the model is maximizing profit, points at a lower NPV than the previous iteration would not be chosen and output would revert to the previous point. Thus, under the assumptions of Scenario 4 the model suggests the plant does not exist. Figure 8 shows furthermore the total plant costs vs. output for Scenario 1 or 4 respectively. This illustrates at points where there is excessive unused $\mathrm{H}_{2}$ output can be increased for a relatively low cost.

Scenario 2 (not shown) yields similar results with Scenario 1, however, the NPV remains at or above 0 within the domain of the model. In contrast, the NPV of Scenario 3 (not shown) is negative at the minimum output simulated and tends further below zero as output increases. This shows the profitability of the plant regardless of the component costs or operational assumptions tends to increase non-linearly in Scenarios 1, 2 and 4.

The high construction cost of the $\mathrm{H}_{2}$ towers prevents smooth output scaling. It is for this reason that an attempt was made to determine an optimum plant size based upon NPV return per initial capital dollar invested. For this the plant size is limited to model iterations producing approximately 1,324 $\mathrm{t} \mathrm{NH}_{3}$ per day (see 2.2) or less using the ratio of NPV over total initial plant costs. This results in an optimum plant size occurring in all four scenarios at the point where $\mathrm{H}_{2}$ use is maximized or, from constraint 1 in Eq.6, $X_{H}-\rho X_{N}$ is minimized. In Scenario 1 this point is found to yield an NPV return per initial investment dollar of 15.2\%. In Scenario 4 the optimum configuration yields a return of $-2.1 \%$. Any deviation from this point within the upper and lower boundaries of the model will reduce the NPV to the initial capital ratio. These results are summarized for all four scenarios in Table 6 .

The implications of an optimum plant size as well as the oscillating profit function are potential barriers to entry and deterrents in plant scale changes. The lowest initial required capital to reach an optimum plant size occurs in Scenario 1 at an initial cost of 769.9 million dollars and an output of $902.2 \mathrm{t} \mathrm{NH}_{3}$ per day. Given this large initial capital requirement for efficient operation operating under the competitive market assumption will in fact generate a fairly large barrier to entry into the market. The oscillation of the profit function implies that 
careful consideration must be taken before increasing the $\mathrm{NH}_{3}$ capacity of any plant operating at optimum or at least at a relative maximum in the profit function. Increasing the $\mathrm{NH}_{3}$ output from either of these points by a fraction will most likely increase the per unit production costs and may even reduce overall profits.

\subsection{Sensitivity to the $\mathrm{NH}_{3}$ sales price}

The sensitivity of the presented model to major operational and economic variables is demonstrated analyzing Scenario 1 to 4 (compare section 2.3 and 3.2) in section 3.3. To assess the effect of the $\mathrm{NH}_{3}$ sales price a sensitivity analysis was conducted determining the required $\mathrm{NH}_{3}$ price to yield a NPV of 0 for all four scenarios within the domain of the model (Fig.9).

At an optimum output of $902.2 \mathrm{t} \mathrm{NH}_{3}$ per day, a zero NPV is achieved in Scenario 1 or 2 by decreasing the Monte Carlo simulated 20 year prices (Fig.7) by $13.5 \%$ or $38.8 \%$ respectively (Fig.9A). That is, the possibility of yielding a negative NPV with a fall in the $\mathrm{NH}_{3}$ sales price is much greater in Scenario 1 than in Scenario 2. On the other hand, at an optimum output of 911.2 t $\mathrm{NH}_{3}$ per day, Scenario 3 or 4 would require $\mathrm{NH}_{3}$ sales prices increased by $39.5 \%$ in Scenario 3 or $2.19 \%$ in Scenario 4 respectively (Fig.9B). This indicates that in Scenario 4 slight variations in $\mathrm{NH}_{3}$ prices will result in economic feasibility of the proposed concept. Given in particular the high cost assumptions for acquiring heliostats, Scenario 3 requires a relatively large increase in $\mathrm{NH}_{3}$ price to "break even".

\section{Conclusions and Outlook}

The solar thermochemical synthesis of ammonia using a molybdenum-based reactant was presented and analyzed from a technical and an economic perspective. Major conclusions are:

- It appears technically feasible to form $\mathrm{NH}_{3}$ with a reaction cycle conducted at near $0.1 \mathrm{MPa}$ and at $\leq 1500 \mathrm{~K}$ and without natural gas or solid reducing agents. This may allow synthesis of artificial nitrogen fertilizer without sophisticated machinery and less depended on the volatility of the natural gas price. As outlined for the U.S., geographical regions with high annual insolation and a relative close supply of coastal or fresh water appear suited for this technology.

- Maximum energy efficiencies of converting solar radiation to the lower heating value of $\mathrm{NH}_{3}$ were estimated (23-30\%) between the efficiency of the industrial 
$\mathrm{NH}_{3}$ synthesis employing coal (about 11\%) or natural gas (up to 66\%). As an aside, this approaches the DOE performance target for solar thermochemical $\mathrm{H}_{2}$ (i.e., $30 \%$ by 2017 or $>35 \%$ by 2020 respectively) [33] and includes convenient storage of $\mathrm{H}_{2}$ in form of $\mathrm{NH}_{3}$. In the future, research addressing yield and kinetics of the $\mathrm{NH}_{3}$ formation via materials design [21], heat integration [48], and solar-tohydrogen technology [33] will be critical for approaching efficiencies realized with the Haber-Bosch process.

- Indirect fossil $\mathrm{CO}_{2}$ emissions (from coal-derived grid-electricity) are in the range of $4-50 \%$ of the $\mathrm{CO}_{2}$ emitted by the current industrial $\mathrm{NH}_{3}$ synthesis employing a coal or natural gas feedstock. Yet, no special monetary benefits for technologies utilizing renewable resources via regulations for example for $\mathrm{CO}_{2}$ emissions are disregarded in the analysis presented.

- The cost of heliostats is a major factor determining the economic feasibility of the proposed technology. About $74-86 \%$ of the heliostat capital investment is absorbed for $\mathrm{H}_{2}$ production. Thus, low cost heliostats (i.e., 90 dollars $/ \mathrm{m}^{2}$ ) or reduced $\mathrm{H}_{2}$ reactor costs ( $<16$ million dollars, as estimated here), or replacing $\mathrm{H}_{2}$ with another gaseous reducing agent, would result in WHAT?? (Scenario 4) or augment (Scenario 1 or 2 at $>450 \mathrm{t} \mathrm{NH}_{3}$ per day) the return of investment.

- $\quad$ The sales price increase of $\mathrm{NH}_{3}$ required for Scenario 4 to break even $(2.19 \%)$ is below the standard deviation of the Monte Carlo Price simulation (5.19\%). Which means what? The present simulation suggests economic feasibility of the proposed technology even under conservative assumptions at $534 \pm 28$ dollars per ton $\mathrm{NH}_{3}$. If natural gas prices rise break even will be possible at production levels below $900 \mathrm{t} \mathrm{NH}_{3}$ per day.

- $\quad$ Production at small scale (down to $144-178 \mathrm{t} \mathrm{NH}_{3}$ per day when employing only a single $\mathrm{H}_{2}$ tower) would reduce initial capital requirements (e.g., 770 million dollars at f??902 $\mathrm{t} \mathrm{NH}$ per day for Scenario 1) and facilitate market entry. Fertilizer production in regions with relatively undeveloped infrastructure for example in developing countries with significant population growth might then be conceivable. 


\section{Acknowledgments}

This material is based upon work supported by National Science Foundation Grant \# 0903701: "Integrating the Socioeconomic, Technical, and Agricultural Aspects of Renewable and Sustainable Biorefining Program, awarded to Kansas State University." Funding by the Center for Sustainable Energy, Kansas State University is kindly acknowledged. 


\section{References}

[1] Smil V. Nitrogen and food production: Proteins for human diets. Ambio. 2002;31(2):126-31. [2] Kramer DA. Nitrogen (fixed) - Ammonia. US Geological Survey, Mineral Commodity Summaries. 2003:118-9.

[3] Parman BJ, Amanor-Boadu V, Pfromm PH, Michalsky R. Third generation biofuels and the food v. fuel debate: a systems perspective. The International Journal of Environmental, Cultural, Economic and Social Sustainability 2011;2:287-300.

[4] a5_www.

[5] Gálvez ME, Halmann M, Steinfeld A. Ammonia production via a two-step A12O3/AlN thermochemical cycle. 1 . Thermodynamic, environmental, and economic analyses. Industrial \& Engineering Chemistry Research. 2007;46(7):2042-6.

[6] Thomas G, Parks G. Potential roles of ammonia in a hydrogen economy, a study of issues related to the use ammonia for on-board vehicular hydrogen storage. US Department of Energy. 2006; http://www.hydrogen.energy.gov/pdfs/nh3 paper.pdf (retrieved 12/2011).

[7] Penner SS. Steps toward the hydrogen economy. Energy. 2006;31(1):33-43.

[8] Lipman T, Shah N. Ammonia as an Alternative Energy Storage Medium for Hydrogen Fuel Cells: Scientific and Technical Review for Near-Term Stationary Power Demonstration Projects (Final Research Report, UCB-ITS-TSRC-RR-2007-5). Institute of Transportation Studies UC Berkeley Transportation Sustainability Research Center (University of California, Berkeley). 2007.

[9] Christensen CH, Johannessen T, Sørensen RZ, Nørskov JK. Towards an ammonia-mediated hydrogen economy? Catalysis Today. 2006;111(1-2):140-4.

[10] Wang P, Kang XD. Hydrogen-rich boron-containing materials for hydrogen storage. Dalton Transactions. 2008(40):5400-13.

[11] Reiter AJ, Kong SC. Combustion and emissions characteristics of compression-ignition engine using dual ammonia-diesel fuel. Fuel. 2011;90(1):87-97.

[12] Kirova-Yordanova Z. Exergy analysis of industrial ammonia synthesis. Energy. 2004;29(12-15):2373-84.

[13] Panjeshahi MH, Langeroudi EG, Tahouni N. Retrofit of ammonia plant for improving energy efficiency. Energy. 2008;33(1):46-64.

[14] Rafiqul I, Weber C, Lehmann B, Voss A. Energy efficiency improvements in ammonia production - perspectives and uncertainties. Energy. 2005;30(13):2487-504.

[15] Ritter SK. The Haber-Bosch reaction: An early chemical impact on sustainability. Chemical \& Engineering News. 2008;86(33):53.

[16] Yandulov DV, Schrock RR. Catalytic reduction of dinitrogen to ammonia at a single molybdenum center. Science. 2003;301(5629):76-8.

[17] Lerch M, Janek J, Becker KD, Berendts S, Boysen H, Bredow T, et al. Oxide nitrides: From oxides to solids with mobile nitrogen ions. Progress in Solid State Chemistry. 2009;37(2-3):81131.

[18] Gálvez ME, Hischier I, Frei A, Steinfeld A. Ammonia production via a two-step A12O3/AlN thermochemical cycle. 3. Influence of the carbon reducing agent and cyclability. Industrial \& Engineering Chemistry Research. 2008;47(7):2231-7.

[19] Gálvez ME, Frei A, Halmann M, Steinfeld A. Ammonia production via a two-step A12O3/AlN thermochemical cycle. 2. Kinetic analysis. Industrial \& Engineering Chemistry Research. 2007;46(7):2047-53. 
[20] Michalsky R, Pfromm PH. Chromium as reactant for solar thermochemical synthesis of ammonia from steam, nitrogen, and biomass at atmospheric pressure. Solar Energy. 2011;85(11):2642-54.

[21] Michalsky R, Pfromm PH. Thermodynamic rationale for designing metal reactants for reactive synthesis of ammonia from steam, nitrogen and biomass at atmospheric pressure. (submitted, AIChE Journal). 2011.

[22] Auner N, Holl S. Silicon as energy carrier - Facts and perspectives. Energy. 2006;31(10-

11):1395-402.

[23] Steinfeld A, Larson C, Palumbo R, Foley M. Thermodynamic analysis of the co-production of zinc and synthesis gas using solar process heat. Energy. 1996;21(3):205-22.

[24] Steinfeld A, Weimer AW. Thermochemical production of fuels with concentrated solar energy. Optics Express. 2010;18(9):A100-A11.

[25] Murray JP, Fletcher EA. Reaction of steam with cellulose in a fluidized-bed using concentrated sunlight. Energy. 1994;19(10):1083-98.

[26] Lédé J. Reaction temperature of solid particles undergoing an endothermal volatilization Application to the fast pyrolysis of biomass. Biomass \& Bioenergy. 1994;7(1-6):49-60.

[27] Barin I, Knacke O. Thermochemical properties of inorganic substances. Berlin Heidelberg New York: Springer-Verlag, 1973.

[28] Wise RS, Markel EJ. Synthesis of high-surface-area molybdenum nitride in mixtures of nitrogen and hydrogen. Journal of Catalysis. 1994;145(2):344-55.

[29] Cairns AG, Gallagher JG, Hargreaves JSJ, McKay D, Morrison E, Rico JL, et al. The influence of precursor source and thermal parameters upon the formation of beta-phase molybdenum nitride. Journal of Alloys and Compounds. 2009;479(1-2):851-4.

[30] Chen H, Lei XL, Liu LR, Liu ZF, Zhu HJ. Structures and electronic properties of $\operatorname{Mo}(2 n) N(n)(n=1-5)$ : a density functional study. Chinese Physics B. 2010;19(12).

[31] Qi J, Jiang LH, Jiang QA, Wang SL, Sun GQ. Theoretical and Experimental Studies on the Relationship between the Structures of Molybdenum Nitrides and Their Catalytic Activities toward the Oxygen Reduction Reaction. Journal of Physical Chemistry C. 2010;114(42):1815966.

[32] Palumbo R, Lédé J, Boutin O, Ricart EE, Steinfeld A, Möller S, et al. The production of Zn from $\mathrm{ZnO}$ in a high-temperature solar decomposition quench process - I. The scientific framework for the process. Chemical Engineering Science. 1998;53(14):2503-17.

[33] Perret R. Solar thermochemical hydrogen production research (STCH), Thermochemical cycle selection and investment priority. Sandia report SAND2011-3622, Sandia National Laboratories. 2011.

[34] Lundberg M. Model-calculations on some feasible 2-step water splitting processes. International Journal of Hydrogen Energy. 1993;18(5):369-76.

[35] Scott Fogler H. Elements of chemical reaction engineering. Upper Saddle River, NJ: Prentice Hall PTR, 2006.

[36] Balta MT, Dincer I, Hepbasli A. Energy and exergy analyses of a new four-step copperchlorine cycle for geothermal-based hydrogen production. Energy. 2010;35(8):3263-72.

[37] a17_www. Aspen Plus Ammonia Model, Aspen Technology, Inc., Version Number V7.0, 2008.

[38] a18_www. http://www.eia.doe.gov/cneaf/electricity/forms/eia920.doc (retrieved January 28, 2012). 
[39] Sturzenegger M, Nüesch P. Efficiency analysis for a manganese-oxide-based thermochemical cycle. Energy. 1999;24(11):959-70.

[40] a15_www. National Solar Radiation Database, 1991-2005 Update: Typical Meteorological Year 3, http://rredc.nrel.gov/solar/old_data/nsrdb/1991-2005/tmy3/by_state_and_city.html\#C (retrieved January 6, 2012).

[41] a16_www. National Solar Radiation Database 1991+2005 Update: User's Manual. Technical Report NREL/TP-581-41364, National Renewable Energy Laboratory. 2007.

[42] Perry RH, Green DW, Maloney JO. Perry's Chemical Engineers' Handbook: McGraw-Hill, New York, 1984.

[43] Logan J, E., Ramendra R. Handbook of Turbomachinery: Marcel Dekker, Inc., New York, 2003.

[44] Maulbetsch JS. Comparison of alternate cooling technologies for California power plants. California Energy Commission and Electrical Power Research Institute (EPRI), Final Report, February 2002 Online available at: http://wwwenergycagov/reports/2002-07-09_500-02079FPDF (retrieved October 15, 2007).

[45] Ernst S. Advances in Nanoporous Materials. Amsterdam: Elsevier, 2009.

[46] a12 www.

[47] Ramezan M, Skone TJ, Nsakala N, Liljedahl GN. Carbon dioxide capture from existing coal-fired power plants. National Energy Technology Laboratory, Final Report (Original Issue Date, December 2006). 2007;DOE/NETL-401/110907.

[48] Lapp J, Davidson JH, Lipiński W. Efficiency of two-step solar thermochemical nonstoichiometric redox cycles with heat recovery. Energy. 2012;37:591-600.

[49] Hacker V, Kordesch K. Ammonia crackers. In: Vielstich W, Lamm A, Gasteiger HA, editors. Handbook of Fuel Cells - Fundamentals, Technology and Applications. Chichester: John Wiley \& Sons, Ltd; 2003. p. 121-7.

[50] a13_www.

[51] a14_www. 


\section{Tables}

\begin{tabular}{|c|c|c|c|}
\hline \multicolumn{4}{|c|}{ Overall process mass balance } \\
\hline Raw materials & $\mathrm{m}(\mathrm{t} / \mathrm{d})$ & $\mathrm{T}(\mathrm{K})$ & $\mathrm{p}(\mathrm{MPa})$ \\
\hline $\begin{array}{l}\text { air } \\
\text { water }\end{array}$ & $\begin{array}{l}1,970 \\
2,418\end{array}$ & $\begin{array}{l}300 \\
293\end{array}$ & $\begin{array}{l}0.1 \\
0.1\end{array}$ \\
\hline Products & $m(t / d)$ & $\mathrm{T}(\mathrm{K})$ & $\mathrm{p}(\mathrm{MPa})$ \\
\hline $\begin{array}{l}\mathrm{NH}_{3}\left(99 w \mathrm{wt} \% \mathrm{NH}_{3} \text { in } \mathrm{H}_{2} \mathrm{O}\right) \\
\mathrm{O}_{2}\left(82 \mathrm{wt} \% \mathrm{O}_{2} \text { in } \mathrm{N}_{2}\right) \\
\text { air }\left(75 w t \% \mathrm{O}_{2}, 12 \mathrm{wt} \% \mathrm{H}_{2} \mathrm{O}\right)\end{array}$ & $\begin{array}{r}1,344 \\
555 \\
2,489\end{array}$ & $\begin{array}{l}306 \\
300 \\
413\end{array}$ & $\begin{array}{c}2 \\
15 \\
0.1\end{array}$ \\
\hline
\end{tabular}

\begin{tabular}{lc}
\hline \multicolumn{2}{c}{ Comparison of total energy requirements $\left(\mathrm{GJ} / \mathrm{N} \mathrm{NH}_{3}\right)$} \\
\hline Solar thermochemical $\mathrm{NH}_{3}{ }^{\text {a }}$ & $56.4-70.6$ \\
Natural gas/steam reforming \& Haber-Bosch ${ }^{\mathrm{b}}$ & $28-40.1$ \\
Coal gasification \& Haber-Bosch c & $47.6-165.9$ \\
Lower heating value $(\mathrm{LHV})$ of $\mathrm{NH}_{3}{ }^{d}$ & 18.6 \\
Gibbs free energy of mixing for $\mathrm{O}_{2}$ separation & 0.2
\end{tabular}

Table 1: Total heat and electricity input; a, ideal operation $\left(Y_{3}=100 \mathrm{~mol} \%, Y_{4}=0 \mathrm{~mol} \%, r_{\text {gas }}=\right.$ $90 \mathrm{~mol} \%$, see 2.1$)$ to conservative operation $\left(Y_{3}=13.9 \mathrm{~mol} \%, Y_{4}=9.1 \mathrm{~mol} \%, r_{\text {gas }}=66.7 \mathrm{~mol} \%\right.$, see 2.1); b, taken from [14] and see 2.2; c, [6, 14]; d, [49]. 


\begin{tabular}{|c|c|c|c|c|c|}
\hline Item category & Unit & $\begin{array}{l}\text { Cost per unit } \\
\text { (U.S. dollars) }\end{array}$ & $\begin{array}{l}\text { Quantity per } \\
\mathrm{NH}_{3} \text { tower }\end{array}$ & $\begin{array}{l}\text { Quantity per } \\
\mathrm{H}_{2} \text { tower }\end{array}$ & Primary source \\
\hline $\begin{array}{l}\text { Mo reactant } \\
\text { Zn reactant } \\
\text { Silica gel }\end{array}$ & $\begin{array}{l}\mathrm{kg} \\
\mathrm{kg} \\
\mathrm{kg}\end{array}$ & $\begin{array}{r}36,000 \\
234 \\
211\end{array}$ & $\begin{array}{r}1,174 \\
59\end{array}$ & 2,288 & $\begin{array}{l}\text { http://www.Ime.com/minormetals/ } \\
\text { http://www.Ime.com/zinc.asp } \\
\text { http://www.ecvv.com/product/2427724.html }\end{array}$ \\
\hline $\begin{array}{l}\mathrm{NH}_{3} \text { reactor } \\
\mathrm{H}_{2} \text { reactor }\end{array}$ & $\begin{array}{l}\text { each } \\
\text { each }\end{array}$ & $\begin{array}{r}8.0 \mathrm{M} \\
16.0 \mathrm{M}\end{array}$ & 1 & 1 & $\begin{array}{l}\text { Mark Jensen, CF Industries, Plant Manager } \\
\text { (April 8, 2011) }\end{array}$ \\
\hline $\begin{array}{l}\text { Water tank } \\
\text { Piping } \\
\text { Water pumps }\end{array}$ & $\begin{array}{l}\text { each } \\
\mathrm{m} \\
\text { each }\end{array}$ & $\begin{array}{l}0.6 \mathrm{M} \\
69 \\
30,000\end{array}$ & $\begin{array}{l}0.16 \\
199\end{array}$ & 1.4 & $\begin{array}{l}\text { Wayne French, VP Tank Builders Inc. (April 8, 2011) } \\
\text { http://www.saginawpipe.com/steel_pipe_chart-3.htm } \\
\text { assumed }\end{array}$ \\
\hline Heliostats & $\mathrm{m}^{2}$ & 164 & 17,006 & 397,039 & $\begin{array}{l}\text { Kolb, G. et al. 2006. "Heliostat Cost Reduction", } \\
\text { project working paper }\end{array}$ \\
\hline Land & $\mathrm{m}^{2}$ & $4.9 \mathrm{M}$ & 21,257 & 496,299 & $\begin{array}{l}\text { Southern California location assumed, http://www.- } \\
\text { bajarealestategroup.net/baja_real_estate/viewcategory/6/ }\end{array}$ \\
\hline Support tower & each & $1.3 \mathrm{M}$ & 1 & 1 & $\begin{array}{l}\text { Mid-Atlantic Regional Space Port, Wallops Island, VA, } \\
\text { Construction Manager (April 5, 2011) }\end{array}$ \\
\hline $\begin{array}{l}\mathrm{HX}<2000 \mathrm{~K} \\
\mathrm{HX}<1500 \mathrm{~K} \\
\mathrm{HX}<500 \mathrm{~K}\end{array}$ & $\begin{array}{l}\mathrm{m}^{2} \\
\mathrm{~m}^{2} \\
\mathrm{~m}^{2}\end{array}$ & $\begin{array}{r}467 \\
467 \\
50\end{array}$ & $\begin{array}{r}2,992 \\
20,160\end{array}$ & 1,944 & $\begin{array}{l}\text { Dennis L. Youchison, Sandia National Laboratories, } \\
\text { Fusion Technology Dept., Albuquerque, NM }\end{array}$ \\
\hline $\begin{array}{l}\text { Air separation } \\
\text { Trucks or trailers } \\
\text { Blowers } \\
\text { Storage tanks } \\
\text { Engineering costs }\end{array}$ & $\begin{array}{l}\text { each } \\
\text { each } \\
\text { each } \\
\mathrm{m}^{2}\end{array}$ & $\begin{array}{l}0.8 \mathrm{M} \\
0.3 \mathrm{M} \\
30,000 \\
60 \\
10 \%\end{array}$ & $\begin{array}{l}0.14 \\
0.59 \\
0.78\end{array}$ & 139.4 & $\begin{array}{l}\text { John Font, Innovative Gas Systems (April 6, 2011) } \\
\text { assumed } \\
\text { http://metalbuildingdepot.com/specials/default.aspx } \\
\text { assumed at } 10 \% \text { total tower construction cost }\end{array}$ \\
\hline
\end{tabular}

Table 2: Cost estimates and necessary quantities for each $\mathrm{NH}_{3}$ and $\mathrm{H}_{2}$ tower (scenario 1 conditions, M marks million, websites information retrieved in April 2011, HX abbreviates heat exchanger). Total costs can be found by the product of each quantity column element and its related cost per unit. 


\begin{tabular}{lcl}
\hline Item category & $\begin{array}{l}\text { Cost per item } \\
\text { (million U.S. dollars) }\end{array}$ & Primary source \\
\hline Compressor $\left(\mathrm{NH}_{3}\right)$ & 0.15 & Mark Jensen, CF Industries, Plant Manager (April 8, 2011) \\
Compressor $\left(\mathrm{O}_{2}\right)$ & 0.15 & assumed \\
Compressor (air) & 0.10 & "' \\
Blower (silica bed) & 0.03 & Mark Jensen, CF Industries, Plant Manager (April 8, 2011) \\
Storage container $\left(\mathrm{NH}_{3}\right)$ & 10.00 & "' \\
Storage container $\left(\mathrm{O}_{2}\right)$ & 14.00 & http://www.solarpaces.org/CSP_Technology/docs/solar_tower.pdf (April, 2011) \\
Master control system & 3.0 &
\end{tabular}

Table 3: Costs of each fixed plant component independent of scale. 


\begin{tabular}{lcll}
\hline Input & $\begin{array}{l}\text { Cost } \\
\text { (U.S. dollars/unit) }\end{array}$ & $\begin{array}{l}\text { Quantity per } \\
\mathbf{N H}_{\mathbf{3}} \text { tower }\end{array}$ & $\begin{array}{l}\text { Quantity per } \\
\mathbf{H}_{\mathbf{2}} \text { tower }\end{array}$ \\
\hline Electricity & $41.79 \mathrm{MWh}^{-1}$ & 1 & - \\
Water & $0.8 \mathrm{t}^{-1}$ & - & $2.29 \mathrm{t}$ \\
Labor (reactors) & 75,000 year-1 & 1 & - \\
Labor (compressors) & 100,000 year-1 & 0.1 & - \\
Labor (piping) & 60,000 year-1 & 0.25 & - \\
Service (heliostats) & $3 \%$ of total heliostat cost & varies & varies \\
\hline Total variable costs $\left(\mathrm{NH}_{3}\right.$ tower $)$ & 133,747 year & & \\
Total variable costs $\left(\mathrm{H}_{2}\right.$ tower $)$ & $1,653,155$ year-1 & &
\end{tabular}

Table 4: Operating costs per tower. The Master Control system labor was assumed at 200,000 dollars. Water cost per ton from [50], electricity cost per MWh from [51], other costs assumed. 


\begin{tabular}{c|c|c}
$\begin{array}{l}\text { Scenario } \\
\text { matrix }\end{array}$ & \multicolumn{1}{|c|}{$\boldsymbol{I = 1}$} & $\boldsymbol{I = 2}$ \\
\hline \multirow{3}{*}{$\mathbf{1}$} & $\delta=6.35$ & $\delta=2.97$ \\
& $\begin{array}{c}\rho=0.262 \\
j=\$ 150 \mathrm{M}+\$ 50 \mathrm{M} \\
\text { to } \max (\$ 1,100 \mathrm{M})\end{array}$ & $\begin{array}{c}\rho=0.146 \\
j=\$ 100 \mathrm{M}+\$ 100 \mathrm{M} \\
\text { to } \max (\$ 1,600 \mathrm{M})\end{array}$ \\
\hline $\boldsymbol{m = 2}$ & $\begin{array}{c}\delta=6.35 \\
\rho=0.262 \\
j=\$ 150 \mathrm{M}+\$ 50 \mathrm{M} \\
\text { to } \max (\$ 1,100 \mathrm{M})\end{array}$ & $\begin{array}{c}\delta=2.97 \\
\rho=0.146 \\
j=\$ 200 \mathrm{M}+\$ 100 \mathrm{M} \\
\text { to } \max (\$ 1,600 \mathrm{M})\end{array}$
\end{tabular}

Table 5: Combination of scenario conditions and parameters (M marks million). 


\begin{tabular}{lrrrr}
\hline & \multicolumn{4}{c}{ Scenario } \\
\cline { 2 - 5 } Category & $\mathbf{1}$ & $\mathbf{2}$ & $\mathbf{3}$ & $\mathbf{4}$ \\
\hline Number of $\mathrm{NH}_{3}$ towers & 19 & 19 & 44 & \multicolumn{1}{c}{44} \\
Number of $\mathrm{H}_{2}$ towers & 5 & \multicolumn{1}{c}{5} & \multicolumn{1}{c}{6} & \multicolumn{1}{c}{6} \\
Output $\left(\mathrm{t} \mathrm{NH}_{3} / \mathrm{d}\right.$ ) & 902.2 & 902.2 & \multicolumn{1}{c}{911.2} & 911.2 \\
\hline Total plant cost (M dollars) & 769.9 & 558.3 & 1138.6 & 932.9 \\
\hline NPV (M dollars) & 116.9 & 337.1 & -346.6 & -19.2 \\
NPV to initial capital ratio (\%) & 15.2 & 60.4 & -30.1 & -2.1
\end{tabular}

Table 6: To outline the optimum plant size: Overall summary of tower quantity, $\mathrm{NH}_{3}$ output, build costs, net present value (NPV), and the NPV to investment ratio at the scenario-specific configuration optimum (M marks million). 


\section{Figures}

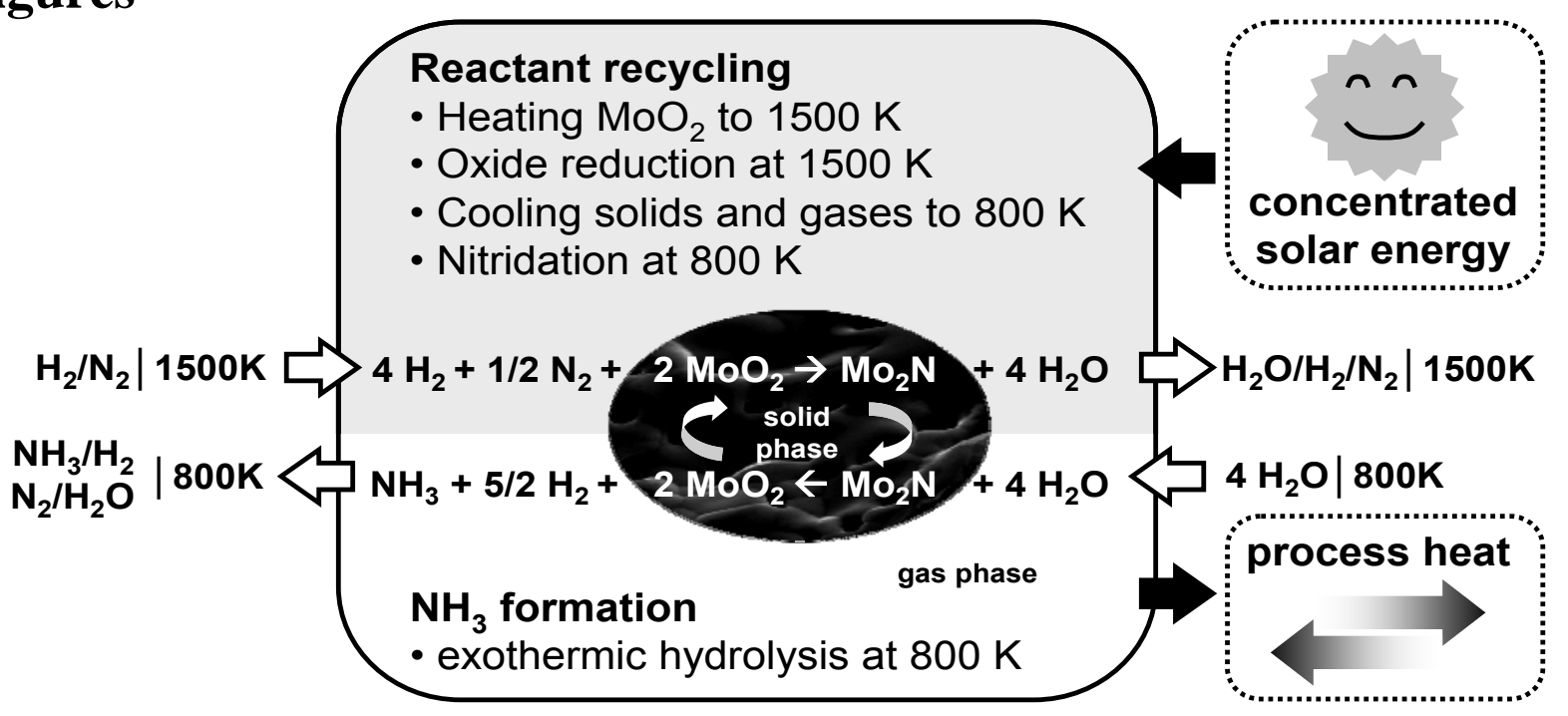

Figure 1: Concept for solar thermochemical $\mathrm{NH}_{3}$ synthesis near atmospheric pressure using a molybdenum reactant. 


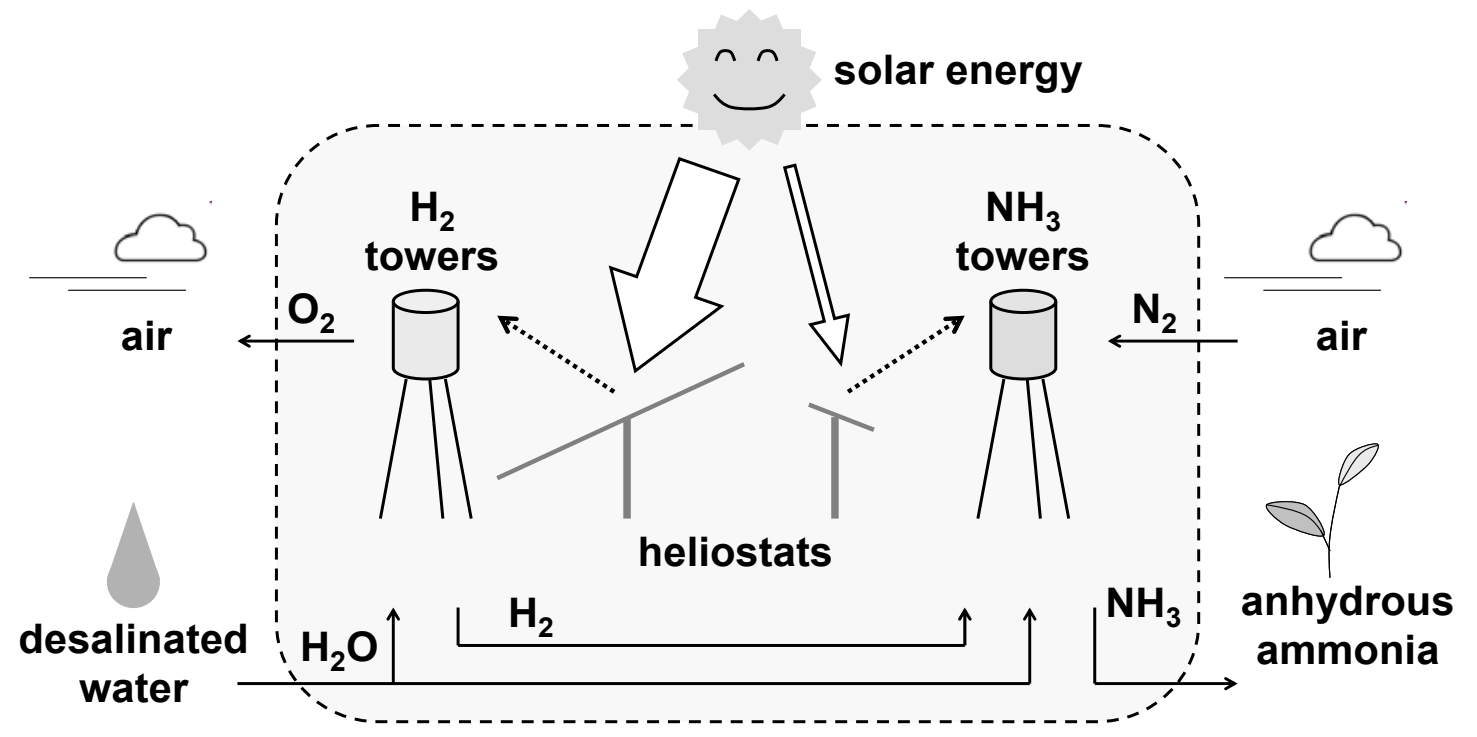

Figure 2: Conceptual implementation of solar thermochemical $\mathrm{NH}_{3}$ synthesis coupled with solar thermochemical $\mathrm{H}_{2}$ synthesis. 

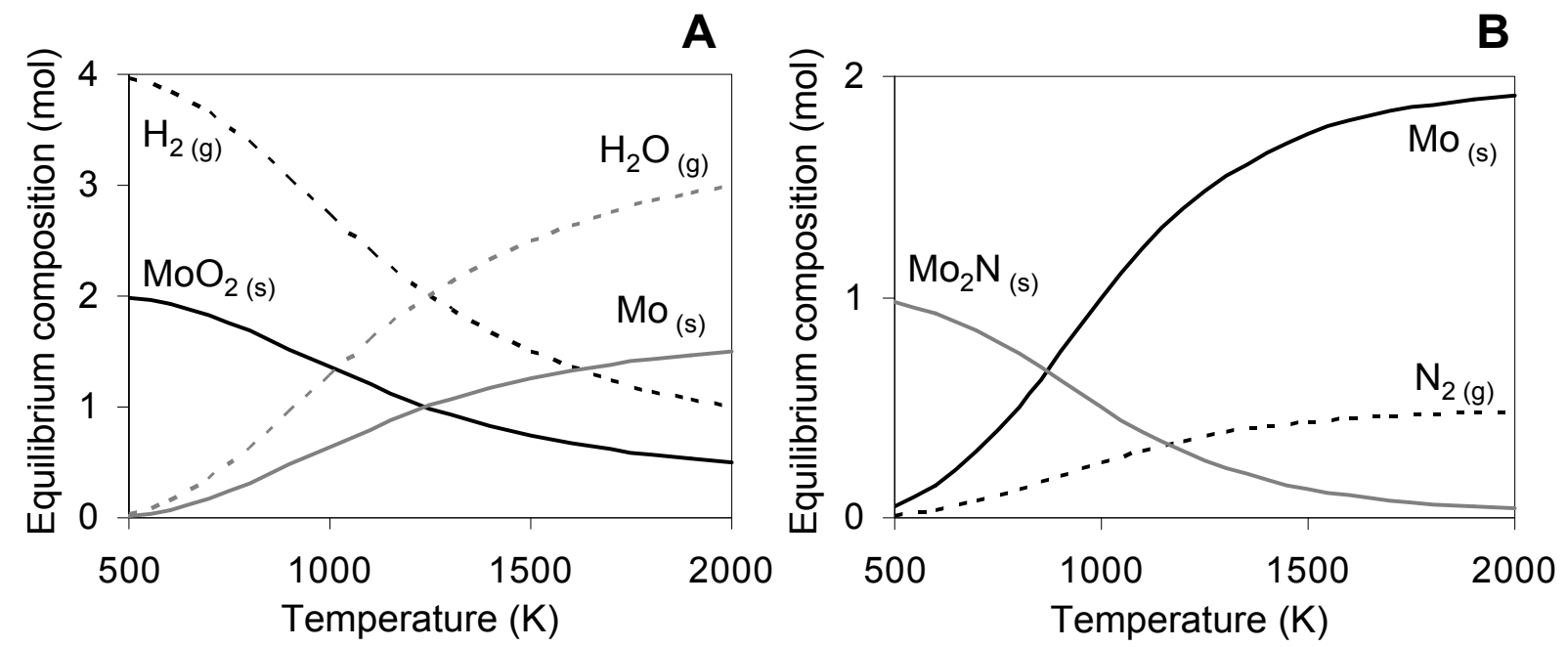

Figure 3: To assess the temperatures that are required for thermodynamic feasibility of the reaction cycle proposed: equilibrium composition of (A) $\mathrm{MoO}_{2}$ reduction (Eq.1) and (B) $\mathrm{N}_{2}$ fixation via Mo nitridation (Eq.2) (see 2.1) as a function of temperature at $0.1 \mathrm{MPa}$. 


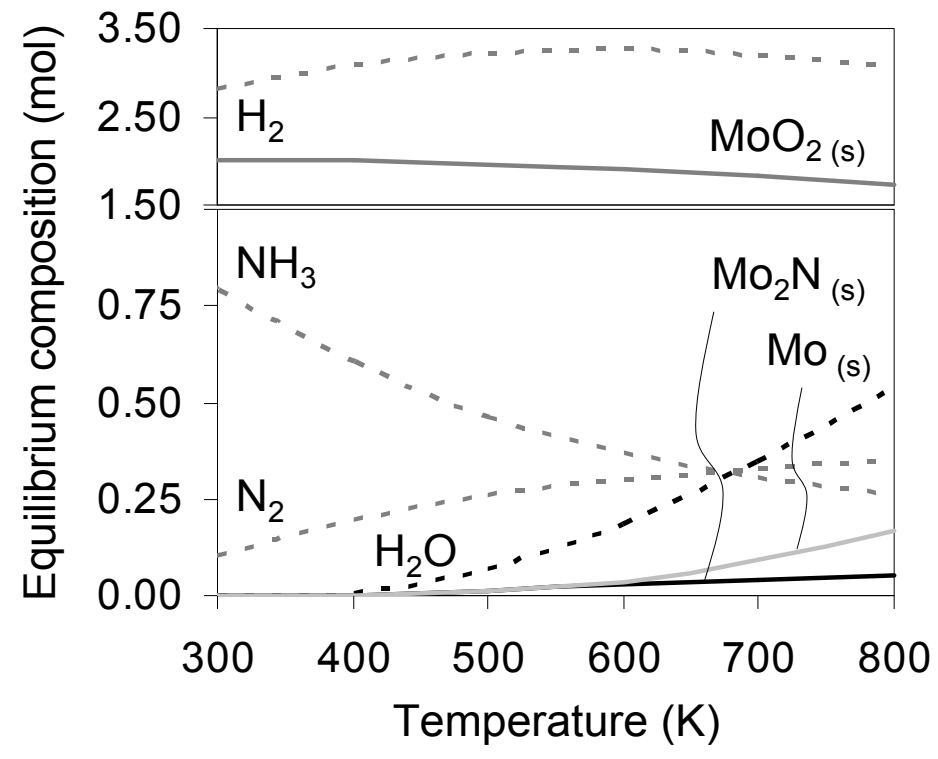

Figure 4: To assess the temperatures that are required for thermodynamic feasibility of the reaction cycle proposed: equilibrium composition of $\mathrm{Mo}_{2} \mathrm{~N}$ hydrolysis forming $\mathrm{MoO}_{2}, \mathrm{NH}_{3}$ and $\mathrm{H}_{2}$ (Eq.3), $\mathrm{Mo}_{2} \mathrm{~N}$ oxidation forming $\mathrm{MoO}_{2}, \mathrm{~N}_{2}$, and $\mathrm{H}_{2}$ (Eq.4) and thermal dissociation of $\mathrm{Mo}_{2} \mathrm{~N}$ forming Mo and $\mathrm{N}_{2}$ (see 2.1) as a function of temperature at $0.1 \mathrm{MPa}$. 


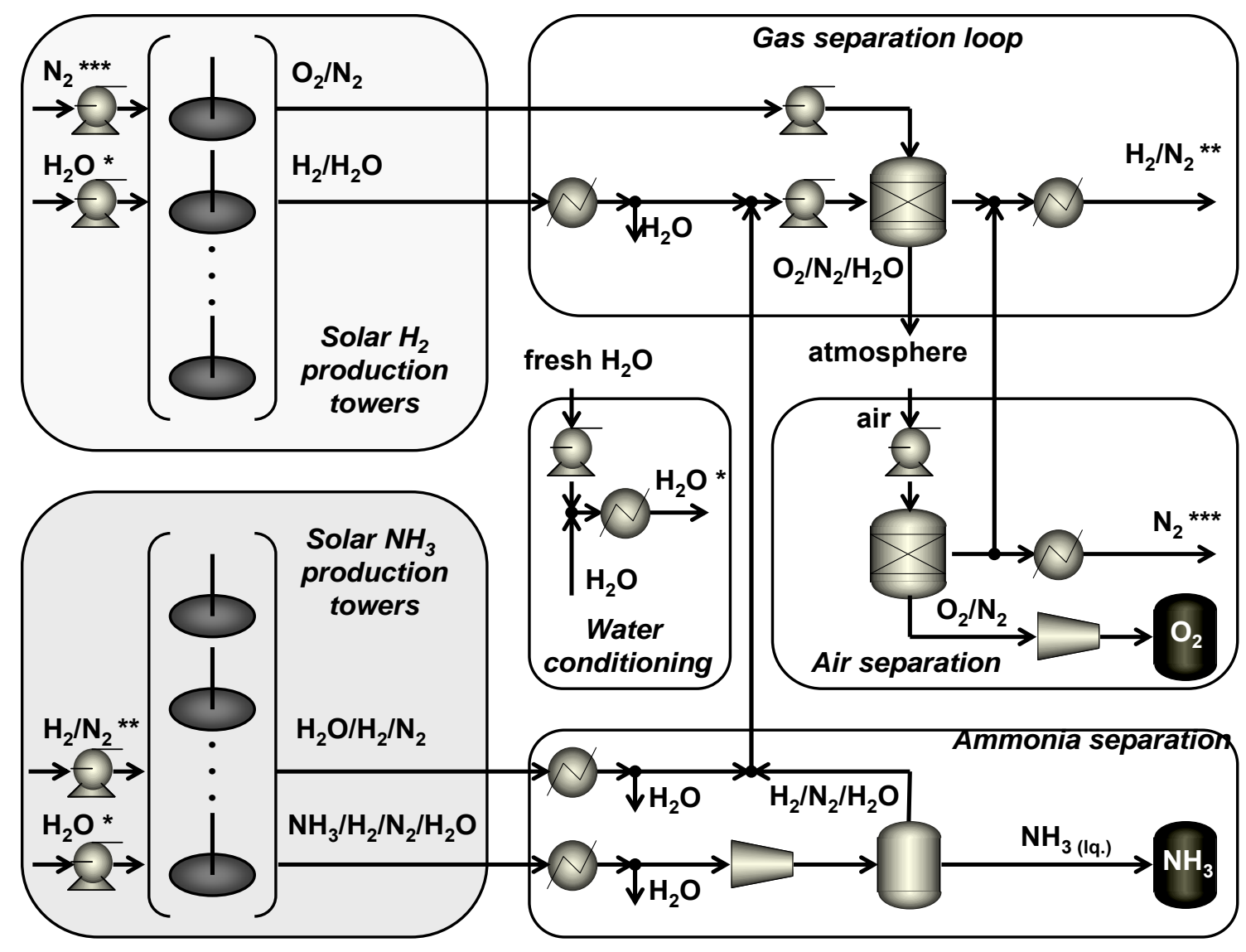

Figure 5: Process schematic of solar thermochemical $\mathrm{NH}_{3}$ synthesis and on-site $\mathrm{H}_{2}$ production (dry cooling system not shown). 
Solar energy (MW)

a) Radiation rejected at all $\mathrm{NH}_{3}$ towers at $1500 \mathrm{~K}$

b) $\Delta_{r x n} h$ of $\mathrm{MoO}_{2}$ reduction at $1500 \mathrm{~K}$

c) Radiation rejected at all $\mathrm{H}_{2}$ towers at $400-2000 \mathrm{~K}$

d) $\Delta_{r \times n} h$ of $\mathrm{ZnO}$ reduction at $2000 \mathrm{~K}$

Electricity \& process heat (MW)

e) Electricity for all operations except cooling

f) Electricity for cooling fan

g) Heat removed via dry cooling at $300-340 \mathrm{~K}$

h) $\Delta_{\text {sens }} h$ for heating $\mathrm{ZnO}$ at 400-2000 K, solar energy

i) heat integrated at $293-2000 \mathrm{~K}$
Ideal operation Conservative operation
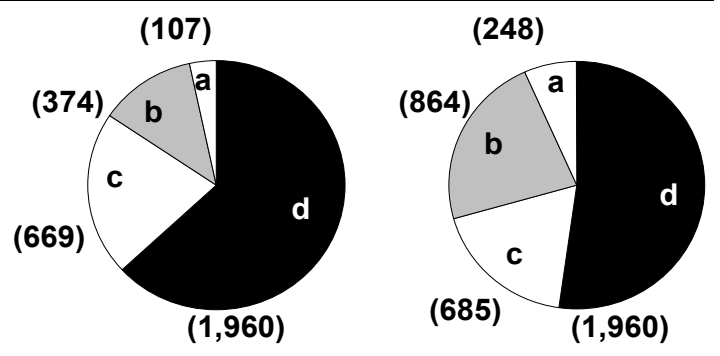

Figure 6: Total power requirements at industrial production scale (producing 1,324 $\mathrm{t} \mathrm{NH}_{3}$ per day, within $7.48 \mathrm{~h} / \mathrm{d}$ operation on average, see 2.1, 2.2 and 2.3). All power values given in brackets are in MW/plant. 


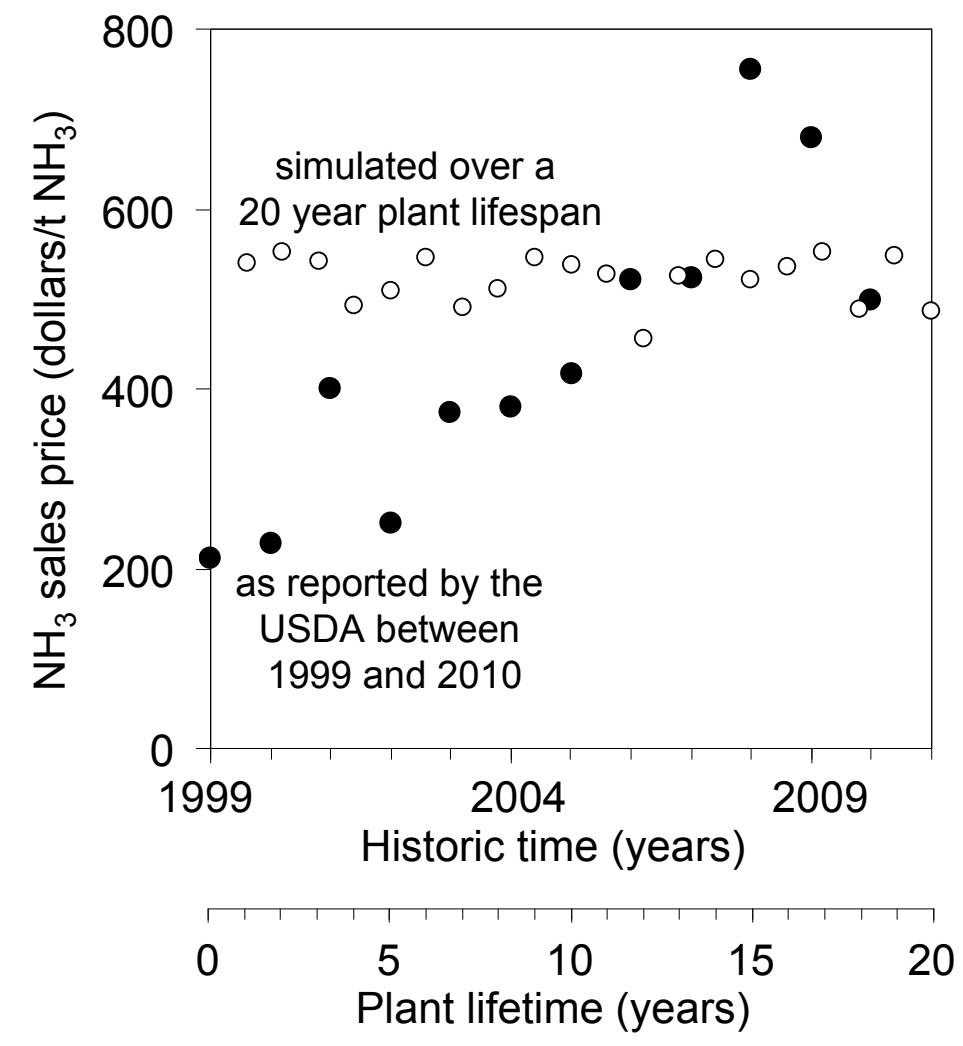

Figure 7: Actual average annual $\mathrm{NH}_{3}$ sales price reported by the USDA between 1999 and 2010 (filled circles) and the Monte Carlo 20-year price simulation with a standard deviation of 27.13 and a mean of 522.24 dollars/t $\mathrm{NH}_{3}$ (empty circles). 


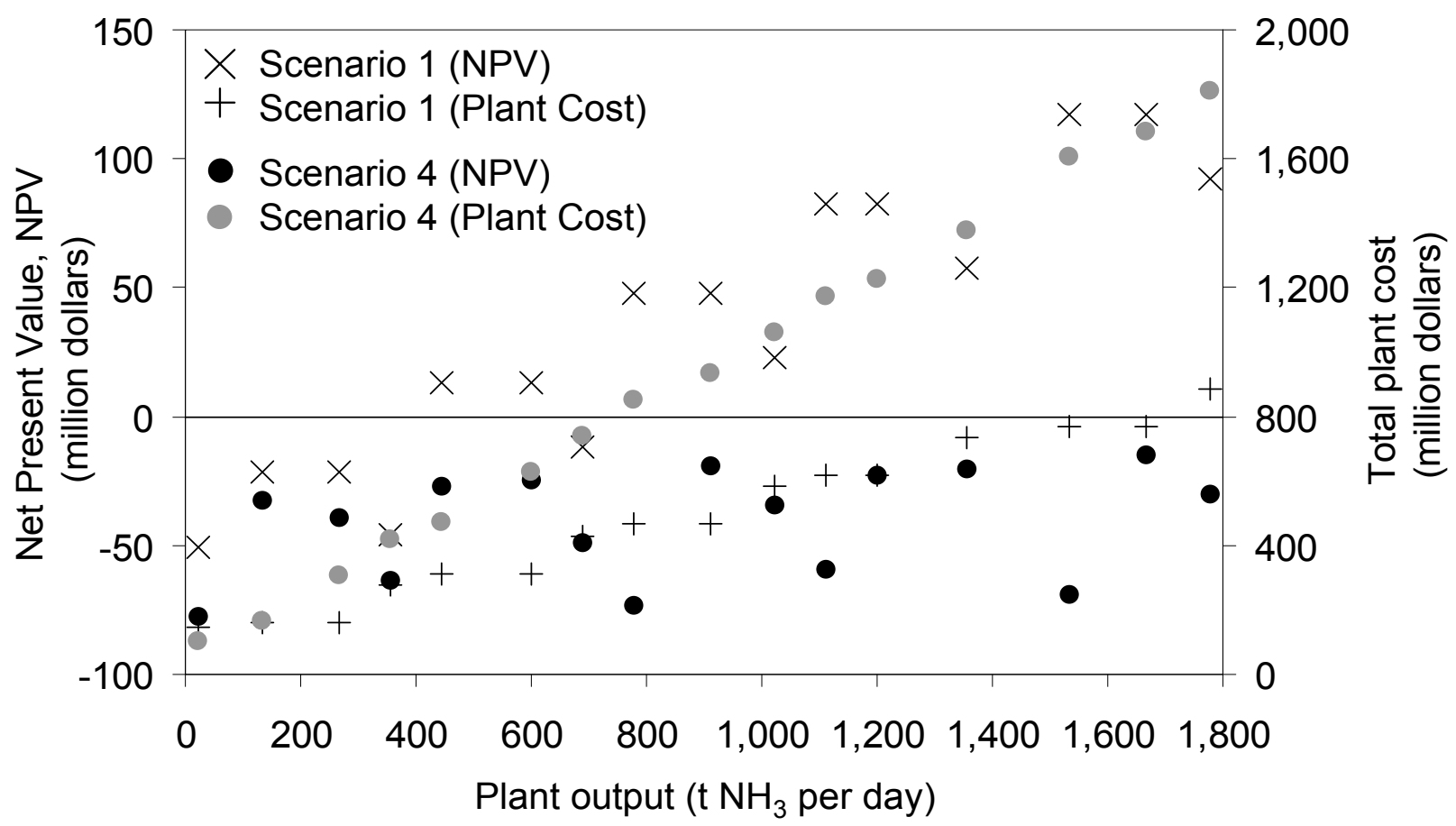

Figure 8: NPV and total initial plant costs as a function of $\mathrm{NH}_{3}$ output (for descriptions of Scenarios 1 or 4 see 2.3 and 3.2). 
Scenario 1 A

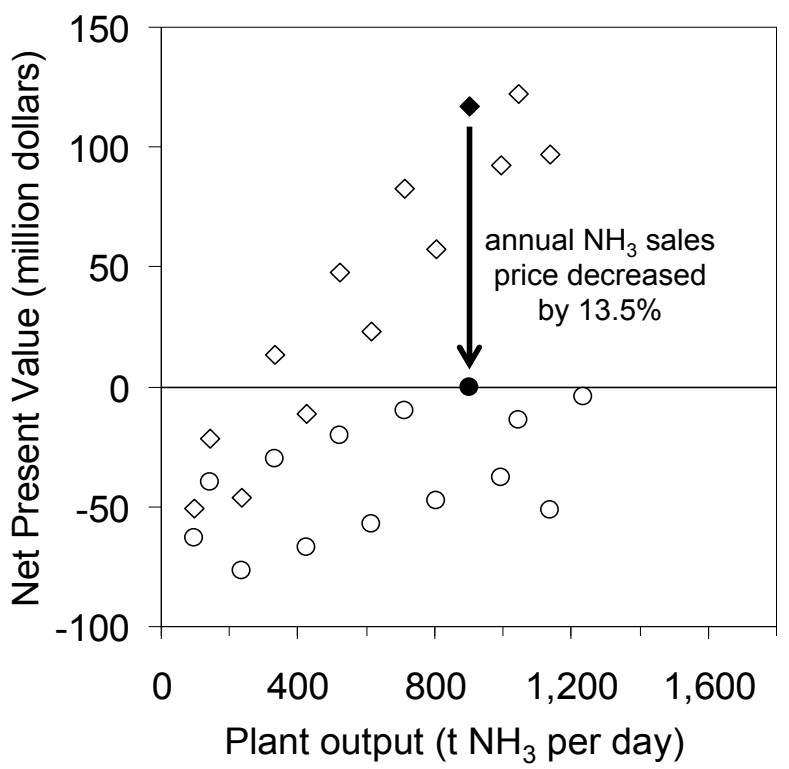

Scenario 4 B

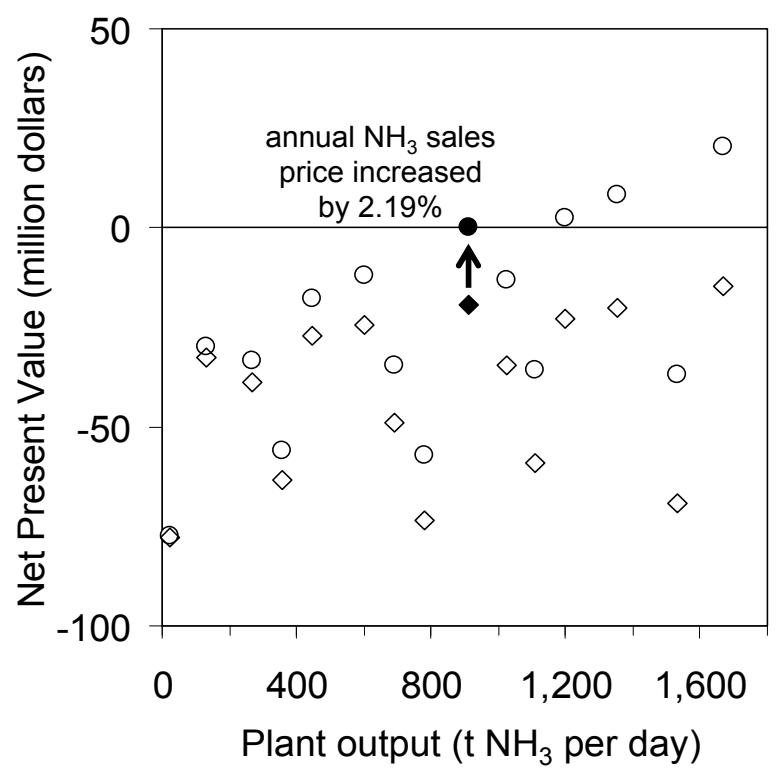

Figure 9: Sensitivity of (A) Scenario 1 or (B) Scenario 4 to variations in the $\mathrm{NH}_{3}$ sales price Monte Carlo-simulated over a 20 year plant lifespan (diamonds mark simulations with baseline$\mathrm{NH}_{3}$ sales prices, see 3.1 and 3.2, circles mark simulations with in- or decreased $\mathrm{NH}_{3}$ sales prices, as indicated, to break even at "optimum plant size" shown with filled symbols, see 3.4). 